Review

\title{
Control of Intracellular Calcium Signaling as a Neuroprotective Strategy
}

\section{R. Scott Duncan ${ }^{\dagger}$, Daryl L. Goad ${ }^{\dagger}$, Michael A. Grillo ${ }^{\dagger}$, Simon Kaja ${ }^{\dagger}$, Andrew J. Payne ${ }^{\dagger}$ and Peter Koulen *}

Vision Research Center and Departments of Ophthalmology and Basic Medical Science, School of Medicine, University of Missouri, 2411 Holmes Street, Kansas City, MO 64108, USA;

E-Mails: duncanrs@umkc.edu (R.S.D); goadd@umkc.edu (D.L.G); mag6y5@umkc.edu (M.A.G.); kajas@umkc.edu (S.K.); paynea@umkc.edu (A.J.P.)

$\dagger$ These authors contributed equally and are listed alphabetically.

* Author to whom correspondence should be addressed; E-Mail: koulenp@umkc.edu; Tel.: +1-816-404-1824; Fax: +1-816-404-1825.

Received: 31 December 2009; in revised form: 5 February 2010 / Accepted: 2 March 2010/ Published: 3 March 2010

\begin{abstract}
Both acute and chronic degenerative diseases of the nervous system reduce the viability and function of neurons through changes in intracellular calcium signaling. In particular, pathological increases in the intracellular calcium concentration promote such pathogenesis. Disease involvement of numerous regulators of intracellular calcium signaling located on the plasma membrane and intracellular organelles has been documented. Diverse groups of chemical compounds targeting ion channels, G-protein coupled receptors, pumps and enzymes have been identified as potential neuroprotectants. The present review summarizes the discovery, mechanisms and biological activity of neuroprotective molecules targeting proteins that control intracellular calcium signaling to preserve or restore structure and function of the nervous system. Disease relevance, clinical applications and new technologies for the identification of such molecules are being discussed.
\end{abstract}


Keywords: calcium; $\mathrm{Ca}^{2+}$; intracellular calcium channel; ion channel; extracellular; intracellular; accessory proteins; associated proteins; G-protein coupled receptors; imaging; microscopy; signaling; neuroprotection; cytoprotection; neurodegeneration; Alzheimer's disease; Huntington's disease; retina

\section{Introduction}

Changes in the intracellular concentration of $\mathrm{Ca}^{2+}$ control a plethora of cellular and physiological processes, including neurotransmitter release, hormone secretion, cell fate and gene expression. As such, the control of the intracellular $\mathrm{Ca}^{2+}$ concentration is critical to the functioning and survival of the cell. In both acute and chronic degenerative diseases of the nervous system the viability and function of neurons is reduced as a result of changes in intracellular calcium signaling. In particular, pathological increases in the intracellular calcium concentration promote such pathogenesis. Furthermore, numerous regulators of intracellular calcium signaling located on the plasma membrane and intracellular organelles have been identified to be involved in many of these pathophysiological processes. Neuroprotective strategies targeting different aspects of the complex control of intracellular $\mathrm{Ca}^{2+}$ signaling are a promising approach for pharmaceutical intervention in degenerative diseases of the nervous system. To this end, diverse groups of chemical compounds targeting ion channels, G-protein coupled receptors, pumps and enzymes have been identified as potential neuroprotectants, each targeting different aspects of fine-tuned control of the intracellular $\mathrm{Ca}^{2+}$ concentration. The present review summarizes the discovery, mechanisms and biological activity of representative neuroprotective molecules targeting proteins that control intracellular calcium signaling to preserve or restore structure and function of the nervous system. Furthermore, disease relevance, clinical applications and new technologies for the identification of such molecules are being discussed.

\section{Intracellular Calcium Channels as Targets for the Development of Neuroprotective Strategies}

Inositol 1,4,5-trisphosphate $\left(\mathrm{IP}_{3}\right)$ receptors $\left(\mathrm{IP}_{3} \mathrm{Rs}\right)$ and ryanodine receptors (RyRs) are the two major intracellular $\mathrm{Ca}^{2+}$ channels (ICCs) that release $\mathrm{Ca}^{2+}$ from intracellular stores such as the endoplasmic reticulum (ER). Release and sequestering of $\mathrm{Ca}^{2+}$ from these intracellular stores is a major determinant in the shape and resting state of intracellular $\mathrm{Ca}^{2+}$ levels. $\mathrm{IP}_{3} \mathrm{Rs}$ and RyRs are critical for $\mathrm{Ca}^{2+}$ dependent processes such as cellular growth, development, gene expression and neurotransmission [1-10]. Aberrant ICC function as a controlling part of overall intracellular $\mathrm{Ca}^{+2}$ handling also plays a role in a variety of neurodegenerative diseases including Alzheimer's disease (AD), Huntington's disease (HD), Amyotrophic lateral sclerosis (ALS), excitotoxicity induced apoptosis, hypoxia, and neuroinflammation [11-18].

The role of ICCs in AD pathology has become more apparent in the last several years. For example, phosphatidylinositol and $\mathrm{IP}_{3}$ levels are reduced in the brains of patients with $\mathrm{AD}$. The decrease in $\mathrm{IP}_{3}$ binding sites in brains of $\mathrm{AD}$ patients correlates with the increased occurrence of amyloid plaques and neurofibrillary tangles [19-24]. In addition, $\mathrm{IP}_{3} \mathrm{R}$ activity is altered in cultured neurons from mouse models of $\mathrm{AD}[13,16,17]$ and in cortical neurons exposed to $\beta$-amyloid protein $(\mathrm{A} \beta)$ resulting in 
increased neuronal death [16]. Mutations in presenilin-1 (PS-1), presenilin-2 (PS-2), or amyloid precursor protein (APP) lead to early adult onset $\mathrm{AD}$, characterized by $\mathrm{A} \beta$ plaques, neuroinflammation, and increased oxidative stress. These mutations have also been linked to alterations in intracellular $\mathrm{Ca}^{2+}$ homeostasis [25], with PS1 and PS2 mutations showing alterations in $\mathrm{IP}_{3} \mathrm{R}$ activity resulting in enhanced $\mathrm{Ca}^{2+}$ release from ER stores [31-32].

In addition, RyR function is directly affected by wild type PS1 [27] and PS2 [28] with mutations in these two proteins leading to enhanced $\mathrm{Ca}^{2+}$ release [29] and vulnerability of cells to apoptosis [30]. Transgenic mutant APP, PS-1, or triple transgenic (PS-1/PS-2/APP) mice exhibit elevated RyR expression, RyR-mediated $\mathrm{Ca}^{2+}$ release, and susceptibility to $\mathrm{A} \beta[14,26]$. This is supported clinically, as $\mathrm{AD}$ patients displaying advanced cognitive decline exhibit changes in neuronal RyR expression and ryanodine binding in specific brain regions where $A \beta$ deposition occurs [11]. A $\beta$ treatment of cultured neurons increases RyR3 expression and RyR-mediated $\mathrm{Ca}^{2+}$ release contributing to neuronal cell death $[16,18]$.

HD is a neurodegenerative disorder characterized by the loss of striatal neurons, neuroinflammation, and increased oxidative stress $[33,34]$. HD is caused by a polyglutamine expansion of the amino terminus of the Huntington protein $(\mathrm{Htt})$, which promotes binding to Huntington-associated protein (HAP1) [35]. In a yeast two-hybrid screen the C-terminus of brain $\mathrm{IP}_{3} \mathrm{R}$ type $1\left(\mathrm{IP}{ }_{3} \mathrm{R} 1\right)$ associates with the HD Htt-HAP1 complex and increases $\mathrm{IP}_{3} \mathrm{R} 1$ sensitivity to activation by $\mathrm{IP}_{3}[36]$. This sensitization of the $\mathrm{IP}_{3} \mathrm{R}$ leads to elevated $\mathrm{Ca}^{2+}$ release and apoptosis in neuronal cells [15]. Furthermore, studies with the YAC128 transgenic HD mouse model have shown that disruption of $\mathrm{IP}_{3} \mathrm{R}$ binding to $\mathrm{Htt}$ reduces glutamate induced apoptosis by stabilizing intracellular $\mathrm{Ca}^{2+}$ homeostasis [37]. Genomic analysis of the R6/2 mouse HD model shows a downregulation in RyR type 1 expression further implicating intracellular $\mathrm{Ca}^{2+}$ induced $\mathrm{Ca}^{2+}$ release (CICR) in the progression of this disease [38].

Amyotrophic lateral sclerosis (ALS) is defined by loss of motor neurons, neuroinflammation, and increased oxidative stress. $T$ cell dysfunction and mutations in the superoxide dismutase 1 (SOD-1) gene have been suggested as possible mechanisms for the progression of this disorder [34,39]. Abnormal IgG from sporadic ALS patients interacts with Cav2.2 N-type calcium channels in motor neurons causing an increase in intracellular $\mathrm{Ca}^{2+}$. This increase in $\mathrm{Ca}^{2+}$ can be ablated by the use of ryanodine and $\mathrm{IP}_{3}$ receptor blockers, suggesting a role for altered CICR and intracellular $\mathrm{Ca}^{2+}$ signaling in ALS [40].

These studies provide a rationale for determining the roles of ICCs in the progression of neurodegenerative diseases as well as for the development of neuroprotective strategies and potential therapeutic agents with ICCs and their signaling and binding partners as targets.

\section{VGCCs as Targets for the Development of Neuroprotective Strategies}

Increase of the intracellular $\mathrm{Ca}^{2+}$ concentration is widely considered the single most important contributor to neurodegeneration and neuronal cell death following ischemic or hypoxic insult [237]. As a consequence, voltage-gated $\mathrm{Ca}^{2+}$ channels (VGCCs) are an important target for the development of neuroprotective strategies, given their central role in depolarization-induced $\mathrm{Ca}^{2+}$ influx [41]. 
VGCCs comprise two groups of high voltage-activated channels, dihydropyridine-sensitive Cav1 (L-type) channels and Cav2 (P/Q-, N- and R-type) channels, as well as low voltage-activated Cav3 (T-type) channels. In addition to the pore-forming $\alpha_{1}$-subunit, high voltage-activated $\mathrm{Ca}^{2+}$ channels form a complex consisting of an additional $\beta-, \alpha_{2} \delta$ - and possibly $\gamma$-subunit. The biophysical properties of VGCCs are largely determined by the specific sub-type and splice variant of the $\alpha_{1}$-subunit, the specific subunit-composition, phosphorylation status as well as the level of channel inactivation (for review, see [41]).

The rationale for considering VGCCs as possible neuroprotective targets is based on the hypothesis that VGCCs respond to the persistent ischemia- or hypoxia-induced depolarization (reviewed in [42]). Based on their extremely fast inactivation kinetics [41,43], Cav3 channels are unlikely contributors to insult-induced $\mathrm{Ca}^{2+}$ load. The pivotal role of Cav2 channels in neurotransmitter release may contribute to an overall insult-induced state of neuronal hyperexcitability, however, their role in contributing to increases in intracellular $\mathrm{Ca}^{2+}$ following insult is questionable, given their localization at the active zone of synapses and their intermediate inactivation kinetics. In contrast, Cav1 (L-type calcium) channels exhibit slow voltage-dependent inactivation [41]. Furthermore, Cav1 channels have been shown to be physically and functionally linked to intracellular $\mathrm{Ca}^{2+}$ release channels such as RyR in neurons $[44,45]$.

In in vitro systems, dihydropyridine blockers of Cav1 channels, such as nimodipine, israpidine, and nicardipine have shown neuroprotective effects by reducing the intracellular rise in $\mathrm{Ca}^{2+}$ following insult $[46,47]$. However, results from in vivo models have been highly variable: whereas some studies found neuroprotective effects of dihydropyridines [48-57], others failed to observe any effect on insult [for review, see 56,58]. The findings of the protective function of nimodipine in animal models of focal cerebral ischemia have been comprehensively reviewed [56].

Clinical trials have failed to show improved outcome after stroke with nimodipine treatment, as recently reviewed by Ginsberg [59]. It should be noted, however, that treatment was initiated at 24 or even $48 \mathrm{hrs}$ after stroke in the majority of these earlier studies. Despite its unquestionable clinical relevance, this timeframe is well beyond the likely useful therapeutic window of nimodipine [59].

Despite these seemingly contradictory in vivo experiments and disappointing clinical trials, Cav1 channels remain a therapeutically-relevant target, as evidence emerges that other known neuroprotective compounds mediate their beneficial effects, at least in part, via Cav1 channels. Nicotine was shown to reduce glutamate excitotoxicity in mouse cortical cultures by lowering intracellular $\mathrm{Ca}^{2+}$ influx by $\sim 40 \%$ through a pathway involving $\beta_{2}$ nicotinic acetylcholinergic receptors, calcineurin and Cav1 channels [60]. Similarly, the hormone vitamin D exerted neuroprotective effects against excitotoxic insult in primary rat hippocampal cultures by reducing Cav1 expression, as determined by measuring L-type $\mathrm{Ca}^{2+}$ currents [61].

A novel broad class of $\mathrm{Ca}^{2+}$ channel blockers purified from the spider toxin of Phoneutria nigriventer has recently been shown to block ischemia-induced glutamate release, neuronal death, and loss of neurotransmission in hippocampal slice preparations subjected to oxygen deprivation and low glucose insult $[62,63]$.

The complex regulation of intracellular $\mathrm{Ca}^{2+}$ homeostasis and the diverse effects of ischemic, excitotoxic or hypoxic insult thereupon may require more than a single molecular target for successful neuroprotective therapeutic intervention. Rational drug design efforts have recently provided 
promising results for neuroprotection: novel tacrine-dihydropyridine hybrids that inhibit both acetylcholinesterase and L-type $\mathrm{Ca}^{2+}$ channel-mediated rises in intracellular $\mathrm{Ca}^{2+}$ have been shown to exert neuroprotective effects in a cellular model for excitotoxic insult [64].

Despite disappointing results from early in vivo animal studies and clinical trials, reducing the activity of dihydropyridine-sensitive $\mathrm{Ca}^{2+}$ channels must continue to be considered in future rational drug design approaches for neuroprotection.

\section{Ionotropic Neurotransmitter Receptors and Their Associated Proteins Controlling Intracellular Calcium Signaling as Targets for the Development of Neuroprotective Strategies}

\subsection{N-methyl-D-aspartic acid (NMDA) receptor activity and neuronal cell death}

The role that NMDA receptors play in long-term potentiation, synaptic plasticity and excitotoxicity in the brain has been extensively studied and is reviewed in detail elsewhere [65-67]. In brief, $\mathrm{Ca}^{2+}$ influx through NMDA receptors and subsequent activation of a variety of signaling events ultimately leads to the expression of proteins involved in synaptic plasticity (reviewed in [67]). Overstimulation of NMDA receptors by glutamate, however, leads to excessive $\mathrm{Ca}^{2+}$ influx resulting in calpain activation and cell death [68]. In retinal ganglion cells (RGCs), glutamate treatment activates NMDA receptors resulting in delayed intracellular $\mathrm{Ca}^{2+}$ dysregulation and cell death while antagonists of NMDA receptors provide protection against toxicity [69]. Numerous basic science studies and clinical trials suggest that NMDA receptor antagonists, such as memantine, show some efficacy as a neuroprotectant in AD, especially if used in combination with other therapies (reviewed in [70,71]). Other novel potential therapeutic targets for neurodegenerative diseases include the modulation of intracellular $\mathrm{Ca}^{2+}$ channel activity and disruption of scaffolding proteins that couple glutamate receptor activity to $\mathrm{Ca}^{2+}$ release from intracellular stores.

\subsection{Functional coupling of intracellular $\mathrm{Ca}^{2+}$ channels to ionotropic glutamate receptors through scaffolding proteins}

Given the critical function of intracellular $\mathrm{Ca}^{2+}$ signaling and ICCs in a variety of cellular functions including protection from cellular insults, scaffolding proteins that structurally or functionally couple them to ionotropic glutamate receptors (iGluRs) are of great importance to the maintenance of normal cellular function. Targeting of a variety of excitatory ionotropic neurotransmitter receptors is achieved through scaffolding proteins such as PSD-95, Chapsyn-110, SAP97, PICK-1, gephyrin, GRIP, ABP and GIPC [72-85]. The importance of ionotropic neurotransmitter receptor targeting underscores the relevance of scaffolding proteins. The activity of ICCs is regulated in part by plasma membrane depolarization by AMPA receptors and subsequent $\mathrm{Ca}^{2+}$ influx generated from NMDA receptors [86-89] making the regulation of iGluRs important for ICC function and overall intracellular $\mathrm{Ca}^{2+}$ signaling.

Actin, itself, can bind to and alter the function of $\mathrm{IP}_{3} \mathrm{Rs}[90]$ and actin depolymerization provides a means for ICC regulation [90-93]. Likewise, treatment of cultured hippocampal neurons with actin destabilizing agents reduces the number of GluR1 AMPA subunit and NR1 NMDA subunit clusters in the dendritic spines of pyramidal neurons [94]. The cytoskeleton also regulates NMDA receptor 
activity in neurons [95]. Given the importance of actin binding to $\mathrm{IP}_{3} \mathrm{Rs}$, NMDA and AMPA receptor subunits, alteration of the actin cytoskeleton may also be a mechanism by which synaptic $\mathrm{Ca}^{2+}$ signals are regulated.

Several studies provide evidence that synaptic scaffolding proteins are critical for maintaining proper neuronal function and viability. Treatment of cultured mouse cortical neurons with F-actin destabilizing agents selectively disrupts NMDA receptor but not AMPA receptor clustering in dendritic spines [96]. Furthermore, disrupting dendritic NMDA receptor clusters with F-actin destabilizing agents reduces excitotoxic cell death in response to increased synaptic glutamate release caused by oxygen-glucose deprivation [96].

Using recombinant mutant NMDA receptor subunits, it was shown that NR2 subunits are required to effectively recruit NR1-1a splice variant subunits into dendritic spines [97]. This effect was partially dependent upon the PDZ domains in NR2 subunits.

\subsection{Ionotropic glutamate receptor function in neurodegenerative disease models}

NMDA receptors are affected in models of AD. Treatment of cortical neurons with $A \beta_{1-42}$ peptide increases endocytosis of NMDA receptor subunits (NR1 and NR2B) [98]. In addition, animals overexpressing $A \beta_{1-42}$ exhibit a reduced surface NMDA receptor density [98]. Cultured neurons from mutant APP transgenic mice exhibit reduced PSD-95 expression and GluR1 AMPA receptor subunit surface expression [99]. PSD-95 knockout mice exhibit an increased number of silent synapses due to a reduced number of functional AMPA receptors [100]. NMDA receptor decay kinetics are also altered due to the possible increase in NR2B versus NR2A NMDA receptor subunit expression [100]. PSD95 targets nNOS to the NMDA receptor thereby coupling $\mathrm{Ca}^{2+}$ influx to nNOS activation [101]. Nitric oxide (NO) produced from neuronal nitric oxide synthase (nNOS) is a mediator of excitotoxicity and disruption of PSD95-nNOS interaction may provide protection from excitotoxicity [101]. Reduction of PSD-95 expression in cultured cortical neurons reduced NMDA receptor-mediated excitotoxicity by uncoupling NMDA receptors to nitric oxide synthase (NOS), a significant contributor to excitotoxic neuronal death [102].

$\mathrm{A} \beta$ dimer and trimer treatment of hippocampal tissue slices leads to a significant decrease in the number and density of dendritic spines in pyramidal neurons [103]. Furthermore, oligomeric $A \beta$ treatment of slice cultures lead to a reduction in NMDA activity [103]. In addition, inhibition of NMDA receptors prevents $A \beta$-mediated dendritic spine loss [103]. Oligomeric $A \beta$ treatment significantly reduced $\mathrm{Ca}^{2+}$ influx though NMDA receptors. In addition, the oligomeric $\mathrm{A} \beta$-mediated reduction in spine density is dependent upon the phosphatase calcineurin and actin destabilization [103]. Overexpression of APP in rat organotypic hippocampal slice cultures results in a reduction in the number of dendritic spines [104]. Furthermore, A $\beta$ reduces glutamatergic transmission through a mechanism similar to long-term depression (LTD) [104]. Hippocampal slices overexpressing APP exhibit reduced excitatory synaptic transmission perhaps providing a negative feedback mechanism for overexcitation and excitotoxicity [105].

Introduction of a GluR2 derived peptide containing a GRIP- and ABP-interacting PDZ domain into hippocampal slices increased AMPA-mediated excitatory postsynaptic current in pyramidal neurons in addition to reducing LTD [78] suggesting that GRIP and ABP reduce AMPA receptor reinsertion. 
Furthermore, PKC phosphorylation of AMPA receptors increases AMPA receptor insertion into the plasma membrane thereby preventing it from interacting with GRIP and ABP [78]. The presence of GluR2 AMPA receptor subunits leads to reduced ion conductance and subsequent excitotoxicity [106]. In a traumatic brain injury model, phosphorylation and subsequent internalization of GluR2 by the PICK1-PKC $\alpha$-PSD-95-NMDA receptor complex results in excitotoxicity [106].

\subsection{Glutamate receptor-ICC coupling as a therapeutic target in neurodegeneration}

NMDA receptors and ICCs functionally interact through a calcium-induced $\mathrm{Ca}^{2+}$ release (CICR) mechanism mediated by RyR and also by regulation of $\mathrm{IP}_{3} \mathrm{Rs}$ by elevated cytosolic $\mathrm{Ca}^{2+}$ concentrations [86-89,107-110]. In addition, $\mathrm{IP}_{3} \mathrm{R}$ and $\mathrm{RyR}$ activity is regulated in part by posttranslational modifications, such as phosphorylation, triggered by upstream signaling events including $\mathrm{Ca}^{2+}$ influx into the cell [111-125].

Furthermore, iGluRs and ICCs interact through a complex network of scaffolding proteins in the postsynaptic density [126-129]. All of these interactions of iGluR with ICC are influenced by scaffolding proteins, which provide a structural assembly mediating the clustering of receptors and facilitating an increase in the proximity among receptor types. Clustering and targeting of iGluRs at synapses, for example, is more efficiently achieved through scaffolding proteins [73,74,80,81]. The trafficking and targeting of ionotropic neurotransmitter receptors to the plasma membrane and physiologically relevant sites such as synapses is critical for neuronal function especially in the context of synaptic plasticity and neuronal cell death. Disruption of iGluR targeting or surface expression of iGluRs likely has a significant effect on ICC activity since plasma membrane depolarization and $\mathrm{Ca}^{2+}$ influx will be reduced.

\section{G-protein Coupled Receptors (GPCR) Linked to the Control of Intracellular Calcium Signaling as Targets for the Development of Neuroprotective Strategies}

\subsection{G-protein coupled receptor signaling}

G-protein coupled receptors (GPCR) are heptahelical plasma membrane proteins, which relay information on extracellular conditions to the cytosol. Despite the large variety of GPCRs, signaling is conveyed through a relatively small number of conserved G-protein signaling pathways. Upon receptor activation the Ga subunit is activated by binding of GTP and dissociation from the inhibitory $\mathrm{G} \beta / \gamma$ dimer [130]. G-protein signaling is sorted into four classes by the effects of the G $\alpha$ subunit - G $\alpha_{\text {s, }}$ $\mathrm{G}_{\mathrm{i} / \mathrm{o}}, \mathrm{G} \alpha \mathrm{q}$, and $\mathrm{G} \alpha 12$ [131]. $\mathrm{G} \alpha_{\mathrm{s}}$ (stimulatory) and $\mathrm{G} \alpha_{\mathrm{i} / \mathbf{o}}$ (inhibitory) modulate the production of cAMP by adenylyl cyclase. cAMP regulates cAMP-dependent protein kinase A (PKA) which affects downstream processes such as cAMP response element binding (CREB) protein activation, neuronal excitability, and gene transcription [130,132]. Phospholipase C (PLC) cleaves phosphatidylinositol bisphosphate (PIP2) to diacylglycerol and $\mathrm{IP}_{3}$ which then activate protein kinase $\mathrm{C}$ (PKC) and calcium release by $\mathrm{IP}_{3} \mathrm{Rs}$, respectively. GPCR signaling mechanisms has been ably reviewed in [133,134] and Gaq signaling was recently reviewed in detail [135]. 


\subsection{Cannabinoid receptors as targets for GPCR-mediated neuroprotection}

The type 1 cannabinoid receptor (CB1) is expressed in the central nervous system (CNS) and has a strong anti-glutamatergic effect. Two endogenous ligands have been identified for CB1, anandamide [136] and 2-arachidonyl glycerol (2-AG) [137,138]. A peptide has recently been proposed as a third endogenous ligand [139]. CB1 receptors are classically thought to inhibit cAMP accumulation in a $\mathrm{Ga}_{\mathrm{i} / \mathbf{o}}$ dependent manner [140,141], but numerous studies have found CB1 linked to calcium responses of interest to neuroprotection. The CB1 agonist WIN55,212-2 was found to inhibit presynaptic N-type and P/Q-Type voltage gated calcium channels (VGCC) [142-144] and inhibited the high-voltageactivated $\mathrm{Ca}^{2+}$ current in rat retinal ganglion cells [145]. WIN55,212-2 also generated a Gaq response though only at relatively high concentrations of $5 \mu \mathrm{M}$ [146]. CB1 receptors have been found at high densities on the presynaptic terminal of glutamatergic synapses [142]. Agonism of CB1 reduced NMDA excitotoxicity [147-151] and inhibited synaptic glutamate release [152]. A PKA-dependent mechanism prophylactic of NMDA excitotoxicity was described by Kim et al. [153]. Zhuang et al., correlate this protective effect to CB1-mediated inhibition of PKA which leads to dephosphorylation of the ryanodine receptor and decreased intracellular calcium release [154]. Promiscuity of the CB1 receptor makes it difficult to attribute its neuroprotective effect to a single action. Though the majority of the data suggests the NMDA receptor as the likely effector, a mechanism has yet to be determined

\subsection{Retinal neuroprotection through the $\alpha 2$ adrenergic receptor}

Glaucoma is characterized by increased intraocular pressure (IOP) and leads to retinal cell death and blindness $[155,156]$. Decreased blood flow of the glaucomatous eye indicates the neuronal damage may be similar to glutamatergic ischemic damage observed elsewhere in the CNS [155]. The $\alpha 2$ adrenergic receptor has been found to decrease glutamate toxicity in the retina [157,158]. NMDA receptors have been detected in the healthy retina $[159,160]$ and toxic concentrations of glutamate were found in the vitreous humor of the glaucomatous eye [161-164]. Treatment with NMDA antagonists is not a viable solution due to side effects $[165,166]$. The NMDA partial agonist memantine was neuroprotective in vitro and certain rodent studies [167-170] but when tested in macaque monkeys memantine only reduced the rate of retinal ganglion cell (RGC) loss and showed no effect on total RGC survival [171,172]. Agonists of the $\alpha 2$ adrenergic receptor have shown promise in preventing cell death [173]. The $\alpha 2$ receptor is expressed in the retina though at a lower level in the outer nuclear layer (ONL) than in the inner layer (INL) [174]. The $\alpha 2$ agonist brimonidine has shown clinical efficacy in reducing IOP [156,175], however, proof of a neuroprotective activity and mechanism is lacking in humans [156]. Pretreatment with brimonidine prevented an increase of the vitreous glutamate concentration and blocked deterioration of the electroretinogram (ERG) b-wave in a rat model of transient retinal ischemia [157]. Brimonidine treatment after retinal damage failed to prevent RGC death [173]. Pretreatment of rat RGCs with the $\alpha 2$ agonists brimonidine or medetomidine inhibited calcium influx through the NMDA receptor and L-type VGCC in the INL but not in the ONL [176]. The observed decrease of calcium influx seems to have been $\alpha 2$-mediated but it is not clear if the effect was due to a $\mathrm{Ga}_{\mathrm{i} / \mathbf{o}}$ mechanism or $\alpha 2$ receptor activation of the inward rectifying $\mathrm{K}^{+}$channel [177]. A follow-up study found that brimonidine neuroprotection against NMDA toxicity required a 
decrease of the intracellular cAMP concentrations by either inhibition of cAMP-specific phosphodiesterase (PDE) or inhibition of adenylyl cyclase [178]. Alternatively, the $G \beta / \gamma$ subunits of the inhibitory G-protein trimer have been found to inhibit VGCCs [179] though that does not seem to be the case in the INL or ONL [176]. Further clarification of the mechanism of action is required but $\alpha 2$ agonists are potentially powerful tools for the treatment of neurodegenerative disorders.

\section{Presenilins as Disease-Relevant Proteins Involved in the Control of Intracellular Calcium Signaling as Targets for the Development of Neuroprotective Strategies}

Presenilins (PS) are ubiquitously expressed in most tissues [180-186] and have been implicated as a causal factor in AD disease progression [1,4,8-14,25,32,180,183,187-191]. PS is a 9-transmembrane aspartyl protease expressed on the ER membrane with two variants (PS1 and PS2) [192-195]. While on the ER, PS is cleaved between the $6^{\text {th }}$ and $7^{\text {th }}$ transmembrane domains $[25,188,193,195]$. Both fragments re-associate and are trafficked to the plasma membrane where they form the proteolytic core of the $\gamma$-secretase complex which cleaves APP including production of A $\beta$ $[25,180,187,189,191,195,196]$. The effects of PS mutations on $\mathrm{Ca}^{2+}$ regulation are profound though mixed [29,31,97-205]. The genetics of AD [206], PS signaling [180] and aspects of calcium signaling in $\mathrm{AD}[25,238]$ were reviewed recently.

Toxic concentrations of $\mathrm{Ca}^{2+}$ in the cytosol have been implicated in neurodegenerative disorders like AD [25,191,202,207,208]. Ischemic conditions are also characterized by increased cytosolic calcium concentrations [200,209-212]. Hypoxia increased PS2 mRNA 10-fold [213] and PS2 expression levels returned to normal within 48 hours of reperfusion [213], potentially indicating increased $\mathrm{Ca}^{2+}$ release during ischemia as a causative mechanism [200,211].

Rybalchenko et al. [27] and Hayrapetyan et al. [28] have recently described a novel mechanism where the N-terminus of PS (PS-NTF) binds to the RyR to increase the mean calcium current and open probability $[27,28]$. Increased RyR open probability resembles an ER calcium leak due to the low level, partial activation of a significant share of RyR while the cell is at rest [27,28]. Binding of PSNTF to RyR could stabilize the open state of the receptor or decrease the energy required for the conformational shifts between closed and open states. PS1-NTF and PS2-NTF provoked very similar responses when bound to the RyR, both fragments increased the amount of time the receptor spent in the open state but neither fragment induced channel gating at sub-threshold calcium concentrations $\left(100 \mathrm{nM} \mathrm{Ca}^{2+}\right)[27,28]$. On the other hand, PS2-NTF blocked desensitization of RyR by inhibitory concentrations of $\mathrm{Ca}^{2+}(>1 \mathrm{mM})$ [27,28] but treatment with PS1-NTF had no effect on calcium inhibition of RyR gating [27,28]. These results indicate that PS1 and PS2 are positive allosteric modulators of RyR that increase the potency of the receptor's endogenous agonist, $\mathrm{Ca}^{2+}$.

An interaction between PS and RyR had been described in other parts of the literature though a specific functional molecular interaction was novel to Rybalchenko et al. [27] and Hayrapetyan et al. [28]. Both NTF and CTF of PS1 were precipitated with RyR2 in PC12 cells [26]. The cleaved CTF of PS2 has been detected bound to RyR [30]. PC12 cells stably transfected with PS1 up-regulate the expression of RyR3 [26]. The same study also found RyR3 up-regulation in a mouse knock-in model of common FAD PS1 mutations [26]. PS has also been reported to act as an ER calcium leak channel [201,214]. In contrast, another study using a different model system strongly contradicts the 
conclusions of Tu and colleagues [32]. Sorcin stabilizes RyRs which increases calcium release [216]. The CTF of proteolytically cleaved PS2 binds to sorcin in a calcium dependent manner [215]. Though no direct link between the PS2-sorcin complex and RyR has been described, SH-SY5Y cells transfected to overexpress PS2 did show increased cytosolic calcium release [215], hypothesized due to a PS2-sorcin-RyR interaction [215].

Cheung et al. (2008) described an analogous interaction between PS and a second class of ER calcium release channels, the $\mathrm{IP}_{3} \mathrm{R}$ [32]. Cheung et al. (2008) reported a PS- $\mathrm{IP}_{3} \mathrm{R}$ interaction that increased receptor open probability and calcium release [32]. This paper's conclusion contradicts data indicating increased $\mathrm{IP}_{3}$ hydrolysis by phospholipase C- $\beta$ (PLC $\beta$ ) in human neuroblastoma SH-SY5Y cells transfected with mutant PS1 containing an exon 9 deletion (PS1 $\Delta$ E9) [188]. PS1 $\Delta$ E9 is a splice variant that is not proteolytically cleaved and therefore not trafficked to the plasma membrane [188]. $\mathrm{PS} 1 \Delta \mathrm{E} 9$ transfected cells stimulated with the muscarinic agonist carbachol displayed increased calcium release but wild type (WT) cells and PS1 transfected cells showed no significant response [188]. Interestingly, human PS2 but not PS1 increased $\mathrm{IP}_{3} \mathrm{R} \mathrm{Ca}^{2+}$ signaling in a Xenopus oocyte system [31].

To date, studies indicate a causal relationship between ER $\mathrm{Ca}^{2+}$ release and PS. Much more work is required to fully define the role of PS in $\mathrm{ER} \mathrm{Ca}^{2+}$ release but the current data indicate therapies could be developed to blunt excessive $\mathrm{Ca}^{2+}$ release found in neurodegenerative conditions like $\mathrm{AD}$ and ischemia.

\section{New Imaging Technologies for Studying the Role of Intracellular Calcium Signaling}

Despite the rapidly evolving knowledge on the role of aberrations in $\mathrm{Ca}^{2+}$ signaling in both acute and chronic neurodegenerative disease, progress in the development of neuroprotective approaches targeting the control of the intracellular $\mathrm{Ca}^{2+}$ concentration have been limited, largely due to the lack of knowledge about the spatio-temporal properties of $\mathrm{Ca}^{2+}$ signaling in different subcellular domains. However, in recent years a number of novel imaging technologies have become available that will help the accurate measuring the intracellular $\mathrm{Ca}^{2+}$ concentration in different sub-compartments and domains of the cell. In the following two subsections advances in the design of novel genetically-encoded $\mathrm{Ca}^{2+}$ sensors and progress in new superresolution microscopy will be reviewed and their potential use for the development of novel neuroprotective strategies be discussed.

\subsection{Small molecule and genetically encoded $\mathrm{Ca}^{2+}$ sensors}

Several new technologies are becoming available for the imaging and quantification of cellular processes by microscopic observation. Some research groups, such as the Tsien laboratory have been working to improve the kinetics, stability, and range of fluorescent sensors [217]; while others, including the Lippincott-Schwartz group, have been creating technologies that expanded the spatial and temporal resolution of microscopic observation and recording in live cells [218]. Small molecule and genetically encoded $\mathrm{Ca}^{2+}$ sensors are characterized by both strengths and weaknesses associated with these different approaches to $\mathrm{Ca}^{2+}$ imaging and quantification. In addition, current superresolution microscopy technologies expand the spatial resolution of light microscopy resulting in improved strategies for measuring intracellular $\mathrm{Ca}^{2+}$ signaling. 
The intensity, quantum efficiency, stability, membrane permeability, toxicity, and kinetic parameters determine the overall experimental usefulness of $\mathrm{Ca}^{2+}$ sensor dyes. No ideal strategy exists for intra-cellular $\mathrm{Ca}^{2+}$ imaging resulting in the need for compromises in experimental design.

The small molecule sensors of intracellular $\mathrm{Ca}^{2+}$ levels are epitomized by the Fura family of calcium sensitive binding dyes. Ratiometric imaging of the Fura2 dye, developed by the Tsien group in 1985 , is considered to be the best method for quantification of $\mathrm{Ca}^{2+}$ concentration in living cells [217,219]. Typically cells are loaded using the plasma membrane permeable acetoxymethyl ester of Fura2 (Fura2-AM). The acetoxymethyl ester moiety is hydrolyzed and cleaved from the Fura2 molecule by the action of endogenous esterases leaving the Fura2 molecule to interact with any free $\mathrm{Ca}^{2+}$ ions in the intracellular milieu. The Fura2 molecule acts as $\mathrm{Ca}^{2+}$ chelator, on binding to free $\mathrm{Ca}^{2+}$ ions, Fura2 changes its peak absorbance wavelength from $\sim 350 \mathrm{~nm}$ to $\sim 340 \mathrm{~nm}$ with a concomitant change, a decrease in absorbance at $380 \mathrm{~nm}$, while its emission maxima remains at $\sim 510 \mathrm{~nm}$. After calibration of Fura2 fluorescent intensities with known $\mathrm{Ca}^{2+}$ concentrations, the intracellular concentrations of $\mathrm{Ca}^{2+}$ can be calculated based on the ratio of changes in fluorescent intensities at $510 \mathrm{~nm}$ with excitation at $340 \mathrm{~nm}$ and $380 \mathrm{~nm}$ in living cells. Fura2 has a $\mathrm{Ca}^{2+}$ binding affinity near physiologic levels and a high selectivity for $\mathrm{Ca}^{2+}$ ions [217,219]. The advantages of these small molecule indicators of $\mathrm{Ca}^{2+}$ includes high selectivity, fast kinetics, and the ability to quantify $\mathrm{Ca}^{2+}$ concentrations using ratiometric imaging. Ratiometric imaging techniques reduce quantification errors caused by indicator concentration, excitation intensity, and detector efficiency. However, ratiometric image analysis is subject to errors [220], resulting in the need for specific controls in the experimental design.

Recently, Tsien and others have been focused on producing Genetically Encoded $\mathrm{Ca}^{2+}$ Indicators (GECIs). Sensors using Förster Resonance Energy Transfer (FRET) pairs or Bimolecular Fluorescence Complementation (BiMC) can be used to quantify $\mathrm{Ca}^{2+}$ levels using ratiometric techniques. However, the fusion of Fluorescent Proteins (FP's) to calcium sensitive proteins is not a trivial task. Fusion of FPs can change the behavior of the sensor, change the protein folding pattern, or cause autophagocytosis of the sensor and in addition consideration of Heisenberg's uncertainty principle of quantum theory [221] is needed as the mere presence of either small molecule sensors or genetically encoded sensors, or even the illumination used to probe the sensors may perturb the cellular mechanism that is being measured.

Tsien's group has produced directed mutations of Green Fluorescent Protein (GFP) from Aequorea victoria and DsRed from Discosoma sp. to form a wide spectrum of genetically encoded fluorescent protein variants. These new genetically encoded fluorescent proteins can be used for multiple spectral and temporal labeling of target proteins and events. These fluorescent proteins can be fused to calcium chelators containing the $\mathrm{C} 2$ domain or the EF hand domain to create genetically encoded $\mathrm{Ca}^{2+}$ sensors, whose construction, coordination, and geometry has been reviewed recently [222]. These constructs can be generated as single fluorophores such as Camgaroo and Peircam, or as FRET based dual fluorophores.

GECIs have expanded the experimental capabilities including targeting the sensor to specific organelles or cellular sites, the generation of transgenic animals, conditional expression, and photoactivation of the indicators. At the same time, the genetically encoded sensors do not share the fast kinetics of the small molecule sensors. The slow kinetics and the lower signal to noise ratio prevents 
detection of fast or weak changes in calcium concentration. However, GECIs continue to be improved. Recently, Tian et al. used structure guided engineering to produce GCaMP3, which has a 3 fold increase in fluorescence, a 3 fold increase in dynamic range, and a 1.3 fold higher affinity for calcium than its parental GCaMP2 sensor [223]. The future of $\mathrm{Ca}^{2+}$ analysis in vivo will likely be dominated by improvements of sensor signal to noise ratios and of binding affinities.

\subsection{Superresolution microscopy}

Advances in light microscopy have led to the breaking of the diffraction limit of resolution. These new methods have been referred to as superresolution microscopy or nanoscopy [224,225]. Until recently light microscopy was limited to about $180-220 \mathrm{~nm}$ resolution laterally and $500-800 \mathrm{~nm}$ axially [226,227]. However several new techniques have been implemented which break the diffraction limited resolution barrier, which have also been reviewed recently [227].

Impressive sub-diffraction limit resolution of point fluorescence sources has been achieved using these methods [227-236]; however, superresolution imaging is not a trivial exercise. Superresolution techniques usually require extremely precise alignment of multiple laser sources, and optical components in addition to requiring substantial computational resources [227]. Gains in axial and lateral resolution may be offset by losses in temporal resolution due to the limitations of computational resources. Optical techniques such as Stimulated Emission Depletion (STED) also face wavelength limitations [227-229].

The combination of new dye technologies with dramatically improved binding affinities and faster kinetics with robust superresolution techniques will be instrumental in measuring the intracellular $\mathrm{Ca}^{2+}$ concentration and study the effects of novel neuroprotective compounds.

\section{Conclusions}

Disease-mediated changes in the regulation of intracellular calcium signaling are characteristic for acute and chronic degenerative diseases of the nervous system as evidenced by studies at the cellular and system level. While the homeostasis of the intracellular calcium concentration is the ultimate readout, numerous molecular and cellular components contribute to the overall change and at the same time represent qualified targets for the design of neuroprotective strategies. The capacity to both identify such targets as well as to reproducibly measure effects on the regulation of intracellular calcium signaling determine critically the success of neuroprotection.

\section{Acknowledgements}

This study was supported in part by grants EY014227 from NIH/NEI, RR022570 from NIH/NCRR and AG010485, AG022550 and AG027956 from NIH/NIA, by The Garvey Texas Foundation and the Felix and Carmen Sabates Missouri Endowed Chair in Vision Research (P.K.). We thank Margaret, Richard and Sara Koulen for generous support and encouragement. 


\section{References and Notes}

1. Hardingham, G.E.; Chawla, S.; Johnson, C.M. Bading, H. Distinct functions of nuclear and cytoplasmic calcium in the control of gene expression. Nature 1997, 385, 260-265.

2. Bading, H. Transcription-dependent neuronal plasticity the nuclear calcium hypothesis. Eur. $J$. Biochem. 2000, 267, 5280-5283.

3. West, A.E.; Chen, W.G.; Dalva, M.B.; Dolmetsch, R.E.; Kornhauser, J.M.; Shaywitz, A.J.; Takasu, M.A.; Tao, X.; M.E. Greenberg. Calcium regulation of neuronal gene expression. Proc. Natl. Acad. Sci. USA 2001, 98, 11024-11031.

4. Simkus, C.R.; Stricker, C. The contribution of intracellular calcium stores to mEPSCs recorded in layer II neurones of rat barrel cortex. J. Physiol. 2002, 545, 521-535.

5. Unni, V.K.; Zakharenko, S.S.; Zablow, L.; DeCostanzo, A.J.; Siegelbaum, S.A. Calcium release from presynaptic ryanodine-sensitive stores is required for long-term depression at hippocampal CA3-CA3 pyramidal neuron synapses. J. Neurosci. 2004, 24, 9612-9622.

6. Dropic, A.J.; Brailoiu, E.; Cooper, R.L. Presynaptic mechanism of action induced by 5-HT in nerve terminals: possible involvement of ryanodine and IP3 sensitive ${ }^{2+}$ stores. Comp. Biochem. Physiol. A Mol. Integr. Physiol. 2005, 142, 355-361.

7. Kelly, P.T.; Mackinnon, R.L., 2nd; Dietz, R.V.; Maher, B.J.; Wang, J. Postsynaptic IP3 receptormediated $\mathrm{Ca}^{2+}$ release modulates synaptic transmission in hippocampal neurons. Brain Res. Mol. Brain Res. 2005, 135, 232-248.

8. Liu, Q.; Chen, B.; Yankova, M.; Morest, D.K.; Maryon, E.; Hand, A.R.; Nonet, M.L.; Wang, Z.W. Presynaptic ryanodine receptors are required for normal quantal size at the Caenorhabditis elegans neuromuscular junction. J. Neurosci. 2005, 25, 6745-6754.

9. Suryanarayanan, A.; Slaughter, M.M. Synaptic transmission mediated by internal calcium stores in rod photoreceptors. J. Neurosci. 2006, 26, 1759-1766.

10. Mathew, S.S.; Hablitz, J.J. Calcium release via activation of presynaptic IP3 receptors contributes to kainate-induced IPSC facilitation in rat neocortex. Neuropharmacology 2008, 55, 106-116.

11. Kelliher, M.; Fastbom, J.; Cowburn, R.F.; Bonkale, W.; Ohm, T.G.; Ravid, R.; Sorrentino, V.; O'Neill, C. Alterations in the ryanodine receptor calcium release channel correlate with Alzheimer's disease neurofibrillary and beta-amyloid pathologies. Neuroscience 1999, 92, 499-513.

12. Bezprozvanny, I.; Hayden, M.R. Deranged neuronal calcium signaling and Huntington disease. Biochem. Biophys. Res. Commun. 2004, 322, 1310-1317.

13. Stutzmann, G.E.; Caccamo, A.; LaFerla, F.M.; Parker, I. Dysregulated IP3 signaling in cortical neurons of knock-in mice expressing an Alzheimer's-linked mutation in presenilin1 results in exaggerated $\mathrm{Ca}^{2+}$ signals and altered membrane excitability. J. Neurosci. 2004, 24, 508-513.

14. Smith, I.F.; Hitt, B.; Green, K.N.; Oddo, S.; LaFerla, F.M. Enhanced caffeine-induced $\mathrm{Ca}^{2+}$ release in the 3xTg-AD mouse model of Alzheimer's disease. J. Neurochem. 2005, 94, 1711-1718. 
15. Tang, T.S.; Slow, E.; Lupu, V.; Stavrovskaya, I.G.; Sugimori, M.; Llinas, R.; Kristal, B.S.; Hayden, M.R.; Bezprozvanny, I. Disturbed $\mathrm{Ca}^{2+}$ signaling and apoptosis of medium spiny neurons in Huntington's disease. Proc. Natl. Acad. Sci. USA 2005, 102, 2602-2607.

16. Ferreiro, E.; Resende, R.; Costa, R.; Oliveira, C.R.; Pereira, C.M. An endoplasmic-reticulumspecific apoptotic pathway is involved in prion and amyloid-beta peptides neurotoxicity. Neurobiol. Dis. 2006, 23, 669-678.

17. Kasri, N.N.; Kocks, S.L.; Verbert, L.; Hebert, S.S.; Callewaert, G.; Parys, J.B.; Missiaen, L.; De Smedt, H. Up-regulation of inositol 1,4,5-trisphosphate receptor type 1 is responsible for a decreased endoplasmic-reticulum $\mathrm{Ca}^{2+}$ content in presenilin double knock-out cells. Cell Calcium. 2006, 40, 41-51.

18. Supnet, C.; Grant, J.; Kong, H.; Westaway, D.; Mayne, M. Amyloid-beta-(1-42) increases ryanodine receptor-3 expression and function in neurons of TgCRND8 mice. J. Biol. Chem. 2006, 281, 38440-38447.

19. Stokes, C.E.; Hawthorne, J.N. Reduced phosphoinositide concentrations in anterior temporal cortex of Alzheimer-diseased brains. J. Neurochem. 1987, 48, 1018-1021.

20. Young, L.T.; Kish, S.J.; Li, P.P.; Warsh, J.J. Decreased brain [3H]inositol 1,4,5-trisphosphate binding in Alzheimer's disease. Neurosci. Lett. 1988, 94, 198-202.

21. Ferrari-DiLeo, G.; Flynn, D.D. Diminished muscarinic receptor-stimulated [3H]-PIP2 hydrolysis in Alzheimer's disease. Life Sci. 1993, 53, 439-444.

22. Crews, F.T.; Kurian, P.; Freund, G. Cholinergic and serotonergic stimulation of phosphoinositide hydrolysis is decreased in Alzheimer's disease. Life Sci 1994, 55, 1993-2002.

23. Garlind, A.; Cowburn, R.F.; Forsell, C.; Ravid, R.; Winblad, B.; Fowler, C.J. Diminished $[3 \mathrm{H}]$ inositol $(1,4,5) \mathrm{P} 3$ but not $[3 \mathrm{H}]$ inositol $(1,3,4,5) \mathrm{P} 4$ binding in Alzheimer's disease brain. Brain Res. 1995, 681, 160-166.

24. Kurumatani, T.; Fastbom, J.; Bonkale, W.L.; Bogdanovic, N.; Winblad, B.; Ohm, T.G.; Cowburn, R.F. Loss of inositol 1,4,5-trisphosphate receptor sites and decreased PKC levels correlate with staging of Alzheimer's disease neurofibrillary pathology. Brain Res. 1998, 796, 209-221.

25. Bezprozvanny, I.; Mattson, M.P. Neuronal calcium mishandling and the pathogenesis of Alzheimer's disease. Trends Neurosci. 2008, 31, 454-463.

26. Chan, S.L.; Mayne, M.; Holden, C.P.; Geiger, J.D.; Mattson, M.P. Presenilin-1 mutations increase levels of ryanodine receptors and calcium release in PC12 cells and cortical neurons. $J$. Biol. Chem. 2000, 275, 18195-18200.

27. Rybalchenko, V.; Hwang, S.Y.; Rybalchenko, N.; Koulen, P. The cytosolic N-terminus of presenilin-1 potentiates mouse ryanodine receptor single channel activity. Int. J. Biochem. Cell Biol. 2008, 40, 84-97.

28. Hayrapetyan, V.; Rybalchenko, V.; Rybalchenko, N.; Koulen, P. The N-terminus of presenilin-2 increases single channel activity of brain ryanodine receptors through direct protein-protein interaction. Cell Calcium 2008, 44, 507-518.

29. Stutzmann, G.E.; Smith, I.; Caccamo, A.; Oddo, S.; Parker, I.; Laferla, F. Enhanced ryanodinemediated calcium release in mutant PS1-expressing Alzheimer's mouse models. Ann. NY Acad. Sci. 2007, 1097, 265-277. 
30. Lee, S.Y.; Hwang, D.Y.; Kim, Y.K.; Lee, J.W.; Shin, I.C.; Oh, K.W.; Lee, M.K.; Lim, J.S.; Yoon, D.Y.; Hwang, S.J.; Hong, J.T. PS2 mutation increases neuronal cell vulnerability to neurotoxicants through activation of caspase-3 by enhancing of ryanodine receptor-mediated calcium release. FASEB J. 2006, 20, 151-153.

31. Leissring, M.A.; Parker, I.; LaFerla, F.M. Presenilin-2 mutations modulate amplitude and kinetics of inositol 1,4,5-trisphosphate-mediated calcium signals. J. Biol. Chem. 1999, 274, 32535-32538.

32. Cheung, K.H.; Shineman, D.; Muller, M.; Cardenas, C.; Mei, L.; Yang, J.; Tomita, T.; Iwatsubo, T.; Lee, V.M.; Foskett, J.K. Mechanism of $\mathrm{Ca}^{2+}$ disruption in Alzheimer's disease by presenilin regulation of InsP3 receptor channel gating. Neuron 2008, 58, 871-883.

33. Qin, Z.H.; Gu, Z.L. Huntingtin processing in pathogenesis of Huntington disease. Acta Pharmacol. Sin. 2004, 25, 1243-1249.

34. Linseman, D.A. Targeting oxidative stress for neuroprotection. Antioxid. Redox. Signal 2009, 11, $421-424$.

35. The Huntington's Disease Collaborative Research Group. A novel gene containing a trinucleotide repeat that is expanded and unstable on Huntington's disease chromosomes. Cell 1993, 72, 971-983.

36. Tang, T.S.; Tu, H.; Chan, E.Y.; Maximov, A.; Wang, Z.; Wellington, C.L.; Hayden, M.R.; Bezprozvanny, I. Huntingtin and huntingtin-associated protein 1 influence neuronal calcium signaling mediated by inositol-(1,4,5) triphosphate receptor type 1. Neuron 2003, 39, 227-239.

37. Tang, T.S.; Guo, C.; Wang, H.; Chen, X.; Bezprozvanny, I. Neuroprotective effects of inositol 1,4,5-trisphosphate receptor C-terminal fragment in a Huntington's disease mouse model. $J$. Neurosci. 2009, 29, 1257-1266.

38. Luthi-Carter, R.; Hanson, S.A.; Strand, A.D.; Bergstrom, D.A.; Chun, W.; Peters, N.L.; Woods, A.M.; Chan, E.Y.; Kooperberg, C.; Krainc, D.; Young, A.B.; Tapscott, S.J.; Olson, J.M. Dysregulation of gene expression in the R6/2 model of polyglutamine disease: parallel changes in muscle and brain. Hum. Mol. Genet. 2002, 11, 1911-1926.

39. Vucic, S.; Kiernan, M.C. Pathophysiology of neurodegeneration in familial amyotrophic lateral sclerosis. Curr. Mol. Med. 2009, 9, 255-272.

40. Pagani, M.R.; Reisin, R.C.; Uchitel, O.D. Calcium signaling pathways mediating synaptic potentiation triggered by amyotrophic lateral sclerosis IgG in motor nerve terminals. J. Neurosci. 2006, 26, 2661-2672.

41. Catterall, W.A. Structure and regulation of voltage-gated $\mathrm{Ca}^{2+}$ channels. Annu. Rev. Cell Dev. Biol. 2000, 16, 521-555.

42. Schurr, A. Neuroprotection against ischemic/hypoxic brain damage: Blockers of ionotropic glutamate receptor and voltage sensitive calcium channels. Curr. Drug Targets 2004, 5, 603-618.

43. Adams, P.J.; Snutch, T.P. Calcium channelopathies: Voltage-gated calcium channels. Subcell Biochem. 2007, 45, 215-251.

44. Chavis, P.; Fagni, L.; Lansman, J.B.; Bockaert, J. Functional coupling between ryanodine receptors and L-type calcium channels in neurons. Nature 1996, 382, 719-722. 
45. Mouton, J.; Marty, I.; Villaz, M.; Feltz, A.; Maulet, Y. Molecular interaction of dihydropyridine receptors with type-1 ryanodine receptors in rat brain. Biochem. J. 2001, 354, 597-603.

46. Krieglstein, J.; Lippert, K.; Poch, G. Apparent independent action of nimodipine and glutamate antagonists to protect cultured neurons against glutamate-induced damage. Neuropharmacology 1996, 35, 1737-1742.

47. Small, D.L.; Monette, R.; Buchan, A.M.; Morley, P. Identification of calcium channels involved in neuronal injury in rat hippocampal slices subjected to oxygen and glucose deprivation. Brain Res. 1997, 753, 209-218.

48. Tally, P.W.; Sundt, T.M.; Anderson, R.E. Improvement of cortical perfusion, intracellular pH, and electrocorticography by nimodipine during transient focal cerebral ischemia. Neurosurgery 1989, 24, 80-87.

49. Lazarewicz, J.W.; Pluta, R.; Puka, M.; Salinska, E. Diverse mechanisms of neuronal protection by nimodipine in experimental rabbit brain ischemia. Stroke 1990, 21, IV108-110.

50. Ohta, S.; Smith, M.L.; Siesjo, B.K. The effect of a dihydropyridine calcium antagonist (isradipine) on selective neuronal necrosis. J. Neurol. Sci. 1991, 103, 109-115.

51. Luiten, P.G.; Douma, B.R.; Van der Zee, E.A.; Nyakas, C. Neuroprotection against NMDA induced cell death in rat nucleus basalis by $\mathrm{Ca}^{2+}$ antagonist nimodipine, influence of aging and developmental drug treatment. Neurodegeneration 1995, 4, 307-314.

52. Campbell, C.A.; Mackay, K.B.; Patel, S.; King, P.D.; Stretton, J.L.; Hadingham, S.J.; Hamilton, T.C. Effects of isradipine, an L-type calcium channel blocker on permanent and transient focal cerebral ischemia in spontaneously hypertensive rats. Exp. Neurol. 1997, 148, 45-50.

53. Kittaka, M.; Giannotta, S.L.; Zelman, V.; Correale, J.D.; DeGiorgio, C.M.; Weiss, M.H.; Zlokovic, B.V. Attenuation of brain injury and reduction of neuron-specific enolase by nicardipine in systemic circulation following focal ischemia and reperfusion in a rat model. $J$. Neurosurg. 1997, 87, 731-737.

54. Zapater, P.; Moreno, J.; Horga, J.F. Neuroprotection by the novel calcium antagonist PCA50938, nimodipine and flunarizine, in gerbil global brain ischemia. Brain Res. 1997, 772, 57-62.

55. Chandra, S.; White, R.F.; Everding, D.; Feuerstein, G.Z.; Coatney, R.W.; Sarkar, S.K.; Barone, F.C. Use of diffusion-weighted MRI and neurological deficit scores to demonstrate beneficial effects of isradipine in a rat model of focal ischemia. Pharmacology 1999, 58, 292-299.

56. Horn, J.; de Haan, R.J.; Vermeulen, M.; Luiten, P.G.; Limburg, M. Nimodipine in animal model experiments of focal cerebral ischemia: A systematic review. Stroke 2001, 32, 2433-2438.

57. Amenta, F.; Tomassoni, D. Treatment with Nicardipine Protects Brain in an Animal Model of Hypertension-Induced Damage. Clin. Exp. Hypertens. 2004, 26, 351-361.

58. Bailey, S.J.; Wood, N.I.; Samson, N.A.; Rothaul, A.L.; Roberts, J.C.; King, P.D.; Hamilton, T.C.; Harrison, D.C.; Hunter, A.J. Failure of isradipine to reduce infarct size in mouse, gerbil, and rat models of cerebral ischemia. Stroke 1995, 26, 2177-2183.

59. Ginsberg, M.D. Neuroprotection for ischemic stroke: Past, present and future. Neuropharmacology 2008, 55, 363-389.

60. Stevens, T.R.; Krueger, S.R.; Fitzsimonds, R.M.; Picciotto, M.R. Neuroprotection by nicotine in mouse primary cortical cultures involves activation of calcineurin and L-type calcium channel inactivation. $J$. Neurosci. 2003, 23, 10093-10099. 
61. Brewer, L.D.; Thibault, V.; Chen, K.C.; Langub, M.C.; Landfield, P.W.; Porter, N.M. Vitamin D hormone confers neuroprotection in parallel with downregulation of L-type calcium channel expression in hippocampal neurons. J. Neurosci. 2001, 21, 98-108.

62. Pinheiro, A.C.; da Silva, A.J.; Prado, M.A.; Cordeiro, M.D.; Richardson, M.; Batista, M.C.; de Castro Junior, C.J.; Massensini, A.R.; Guatimosim, C.; Romano-Silva, M.A.; Kushmerick, C.; Gomez, M.V. Phoneutria spider toxins block ischemia-induced glutamate release, neuronal death, and loss of neurotransmission in hippocampus. Hippocampus 2009, 19, 1123-1129.

63. Pinheiro, A.C.N.; Gomez, R.S.; Massensini, A.R.; Cordeiro, M.N.; Richardson, M.; RomanoSilva, M.A.; Prado, M.A.M.; Marco, L.D.; Gomez, M.V. Neuroprotective effect on brain injury by neurotoxins from the spider Phoneutria nigriventer. Neurochem. Int. 2006, 49, 543-547.

64. León, R.; Ríos, C.d.1.; Marco-Contelles, J.; Huertas, O.; Barril, X.; Javier Luque, F.; López, M.G.; García, A.G.; Villarroya, M. New tacrine-dihydropyridine hybrids that inhibit acetylcholinesterase, calcium entry, and exhibit neuroprotection properties. Bioorg. Medicinal Chem. 2008, 16, 7759-7769.

65. Arundine, M.; Tymianski, M. Molecular mechanisms of calcium-dependent neurodegeneration in excitotoxicity. Cell Calcium 2003, 34, 325-337.

66. Waxman, E.A.; Lynch, D.R. N-methyl-D-aspartate receptor subtypes: Multiple roles in excitotoxicity and neurological disease. Neuroscientist 2005, 11, 37-49.

67. Rao, V.R.; Finkbeiner, S. NMDA and AMPA receptors: Old channels, new tricks. Trends Neurosci. 2007, 30, 284-291.

68. del Cerro, S.; Arai, A.; Kessler, M.; Bahr, B.A.; Vanderklish, P.; Rivera, S.; Lynch, G. Stimulation of NMDA receptors activates calpain in cultured hippocampal slices. Neurosci. Lett. 1994, 167, 149-152.

69. Hartwick, A.T.; Hamilton, C.M.; Baldridge, W.H. Glutamatergic calcium dynamics and deregulation of rat retinal ganglion cells. J. Physiol. 2008, 586, 3425-3446.

70. McKeage, K. Memantine: A review of its use in moderate to severe Alzheimer's disease. CNS Drugs 2009, 23, 881-897.

71. Thomas, S.J.; Grossberg, G.T. Memantine: A review of studies into its safety and efficacy in treating Alzheimer's disease and other dementias. Clin. Interv. Aging. 2009, 4, 367-377.

72. Kornau, H.C.; Schenker, L.T.; Kennedy, M.B.; Seeburg, P.H. Domain interaction between NMDA receptor subunits and the postsynaptic density protein PSD-95. Science 1995, 269, 1737-1740.

73. Kim, E.; Cho, K.O.; Rothschild, A.; Sheng, M. Heteromultimerization and NMDA receptorclustering activity of Chapsyn-110, a member of the PSD-95 family of proteins. Neuron 1996, 17, 103-113.

74. Niethammer, M.; Kim, E.; Sheng, M. Interaction between the C terminus of NMDA receptor subunits and multiple members of the PSD-95 family of membrane-associated guanylate kinases. J. Neurosci. 1996, 16, 2157-2163.

75. Dong, H.; O'Brien, R.J.; Fung, E.T.; Lanahan, A.A.; Worley, P.F.; Huganir, R.L. GRIP: A synaptic PDZ domain-containing protein that interacts with AMPA receptors. Nature 1997, 386, 279-284. 
76. Kneussel, M.; Brandstatter, J.H.; Laube, B.; Stahl, S.; Muller, U.; Betz, H. Loss of postsynaptic GABA(A) receptor clustering in gephyrin-deficient mice. J. Neurosci. 1999, 19, 9289-9297.

77. Xia, J.; Zhang, X.; Staudinger, J.; Huganir, R.L. Clustering of AMPA receptors by the synaptic PDZ domain-containing protein PICK1. Neuron 1999, 22, 179-187.

78. Daw, M.I.; Chittajallu, R.; Bortolotto, Z.A.; Dev, K.K.; Duprat, F.; Henley, J.M.; Collingridge, G.L.; Isaac, J.T. PDZ proteins interacting with C-terminal GluR2/3 are involved in a PKCdependent regulation of AMPA receptors at hippocampal synapses. Neuron 2000, 28, 873-886.

79. Al-Hallaq, R.A.; Yasuda, R.P.; Wolfe, B.B. Enrichment of N-methyl-D-aspartate NR1 splice variants and synaptic proteins in rat postsynaptic densities. J. Neurochem. 2001, 77, 110-119.

80. Hirbec, H.; Francis, J.C.; Lauri, S.E.; Braithwaite, S.P.; Coussen, F.; Mulle, C.; Dev, K.K.; Coutinho, V.; Meyer, G.; Isaac, J.T.; Collingridge, G.L.; Henley, J.M. Rapid and differential regulation of AMPA and kainate receptors at hippocampal mossy fibre synapses by PICK1 and GRIP. Neuron 2003, 37, 625-638.

81. Rumbaugh, G.; Sia, G.M.; Garner, C.C.; Huganir, R.L. Synapse-associated protein-97 isoformspecific regulation of surface AMPA receptors and synaptic function in cultured neurons. $J$. Neurosci. 2003, 23, 4567-4576.

82. Gardner, S.M.; Takamiya, K.; Xia, J.; Suh, J.G.; Johnson, R.; Yu, S.; Huganir, R.L. Calciumpermeable AMPA receptor plasticity is mediated by subunit-specific interactions with PICK1 and NSF. Neuron 2005, 45, 903-915.

83. Hanley, J.G.; Henley, J.M. PICK1 is a calcium-sensor for NMDA-induced AMPA receptor trafficking. EMBO J. 2005, 24, 3266-3278.

84. Liu, S.J.; Cull-Candy, S.G. Subunit interaction with PICK and GRIP controls $\mathrm{Ca}^{2+}$ permeability of AMPARs at cerebellar synapses. Nat. Neurosci. 2005, 8, 768-775.

85. Yi, Z.; Petralia, R.S.; Fu, Z.; Swanwick, C.C.; Wang, Y.X.; Prybylowski, K.; Sans, N.; Vicini, S.; Wenthold, R.J. The role of the PDZ protein GIPC in regulating NMDA receptor trafficking. J. Neurosci. 2007, 27, 11663-11675.

86. Kocsis, J.D.; Rand, M.N.; Chen, B.; Waxman, S.G.; Pourcho, R. Kainate elicits elevated nuclear calcium signals in retinal neurons via calcium-induced calcium release. Brain Res. 1993, 616, 273-282.

87. Lazarewicz, J.W.; Rybkowski, W.; Sadowski, M.; Ziembowicz, A.; Alaraj, M.; Wegiel, J.; Wisniewski, H.M. N-methyl-D-aspartate receptor-mediated, calcium-induced calcium release in rat dentate gyrus/CA4 in vivo. J. Neurosci. Res. 1998, 51, 76-84.

88. Emptage, N.; Bliss, T.V.; Fine, A. Single synaptic events evoke NMDA receptor-mediated release of calcium from internal stores in hippocampal dendritic spines. Neuron 1999, 22, $115-124$.

89. Yoshimura, H.; Sugai, T.; Onoda, N.; Segami, N.; Kato, N. Age-dependent occurrence of synchronized population oscillation suggestive of a developing functional coupling between NMDA and ryanodine receptors in the neocortex. Brain Res. Dev. Brain. Res. 2002, 136, 63-68.

90. Fukatsu, K.; Bannai, H.; Zhang, S.; Nakamura, H.; Inoue, T.; Mikoshiba, K. Lateral diffusion of inositol 1,4,5-trisphosphate receptor type 1 is regulated by actin filaments and $4.1 \mathrm{~N}$ in neuronal dendrites. J. Biol. Chem. 2004, 279, 48976-48982. 
91. Wang, Y.; Mattson, M.P.; Furukawa, K. Endoplasmic reticulum calcium release is modulated by actin polymerization. $J$. Neurochem. 2002, 82, 945-952.

92. Turvey, M.R.; Fogarty, K.E.; Thorn, P. Inositol (1,4,5)-trisphosphate receptor links to filamentous actin are important for generating local $\mathrm{Ca}^{2+}$ signals in pancreatic acinar cells. $J$. Cell Sci. 2005, 118, 971-980.

93. Bose, D.D.; Thomas, D.W. The actin cytoskeleton differentially regulates NG115-401L cell ryanodine receptor and inositol 1,4,5-trisphosphate receptor induced calcium signaling pathways. Biochem. Biophys. Res. Commun. 2009, 379, 594-599.

94. Allison, D.W.; Gelfand, V.I.; Spector, I.; Craig, A.M. Role of actin in anchoring postsynaptic receptors in cultured hippocampal neurons: Differential attachment of NMDA versus AMPA receptors. J. Neurosci. 1998, 18, 2423-2436.

95. Lei, S.; Czerwinska, E.; Czerwinski, W.; Walsh, M.P.; MacDonald, J.F. Regulation of NMDA receptor activity by F-actin and myosin light chain kinase. J. Neurosci. 2001, 21, 8464-8472.

96. Sattler, R.; Xiong, Z.; Lu, W.Y.; MacDonald, J.F.; Tymianski, M. Distinct roles of synaptic and extrasynaptic NMDA receptors in excitotoxicity. J. Neurosci. 2000, 20, 22-33.

97. Barria, A.; Malinow, R. Subunit-specific NMDA receptor trafficking to synapses. Neuron 2002, 35, 345-353.

98. Snyder, E.M.; Nong, Y.; Almeida, C.G.; Paul, S.; Moran, T.; Choi, E.Y.; Nairn, A.C.; Salter, M.W.; Lombroso, P.J.; Gouras, G.K.; Greengard, P. Regulation of NMDA receptor trafficking by amyloid-beta. Nat. Neurosci. 2005, 8, 1051-1058.

99. Almeida, C.G.; Tampellini, D.; Takahashi, R.H.; Greengard, P.; Lin, M.T.; Snyder, E.M.; Gouras, G.K. Beta-amyloid accumulation in APP mutant neurons reduces PSD-95 and GluR1 in synapses. Neurobiol. Dis. 2005, 20, 187-198.

100. Beique, J.C.; Lin, D.T.; Kang, M.G.; Aizawa, H.; Takamiya, K.; Huganir, R.L. Synapse-specific regulation of AMPA receptor function by PSD-95. Proc. Natl. Acad. Sci. USA 2006, 103, $19535-19540$.

101. Cao, J.; Viholainen, J.I.; Dart, C.; Warwick, H.K.; Leyland, M.L.; Courtney, M.J. The PSD95nNOS interface: A target for inhibition of excitotoxic p38 stress-activated protein kinase activation and cell death. J. Cell Biol. 2005, 168, 117-126.

102. Sattler, R.; Xiong, Z.; Lu, W.Y.; Hafner, M.; MacDonald, J.F.; Tymianski, M. Specific coupling of NMDA receptor activation to nitric oxide neurotoxicity by PSD-95 protein. Science 1999, 284, 1845-1848.

103. Shankar, G.M.; Bloodgood, B.L.; Townsend, M.; Walsh, D.M.; Selkoe, D.J.; Sabatini, B.L. Natural oligomers of the Alzheimer amyloid-beta protein induce reversible synapse loss by modulating an NMDA-type glutamate receptor-dependent signaling pathway. J. Neurosci. 2007, 27, 2866-2875.

104. Hsieh, H.; Boehm, J.; Sato, C.; Iwatsubo, T.; Tomita, T.; Sisodia, S.; Malinow, R. AMPAR removal underlies Abeta-induced synaptic depression and dendritic spine loss. Neuron 2006, 52, 831-843.

105. Kamenetz, F.; Tomita, T.; Hsieh, H.; Seabrook, G.; Borchelt, D.; Iwatsubo, T.; Sisodia, S.; Malinow, R. APP processing and synaptic function. Neuron 2003, 37, 925-937. 
106. Bell, J.D.; Park, E.; Ai, J.; Baker, A.J. PICK1-mediated GluR2 endocytosis contributes to cellular injury after neuronal trauma. Cell Death Differ. 2009, 16, 1665-1680.

107. Challis, R.A.; Mistry, R.; Gray, D.W.; Nahorski, S.R. Modulation of muscarinic cholinoceptorstimulated inositol 1,4,5-trisphosphate accumulation by $\mathrm{N}$-methyl-D-aspartate in neonatal rat cerebral cortex. Neuropharmacology 1994, 33, 15-25.

108. Hayashi, T.; Kagaya, A.; Takebayashi, M.; Oyamada, T.; Inagaki, M.; Tawara, Y.; Yokota, N.; Horiguchi, J.; Su, T.P.; Yamawaki, S. Effect of dantrolene on KCl- or NMDA-induced intracellular $\mathrm{Ca}^{2+}$ changes and spontaneous $\mathrm{Ca}^{2+}$ oscillation in cultured rat frontal cortical neurons. J. Neural. Transm. 1997, 104, 811-824.

109. Young, K.W.; Garro, M.A.; Challiss, R.A.; Nahorski, S.R. NMDA-receptor regulation of muscarinic-receptor stimulated inositol 1,4,5-trisphosphate production and protein kinase $\mathrm{C}$ activation in single cerebellar granule neurons. J. Neurochem. 2004, 89, 1537-1546.

110. Gao, W.J.; Goldman-Rakic, P.S. NMDA receptor-mediated epileptiform persistent activity requires calcium release from intracellular stores in prefrontal neurons. Exp. Neurol. 2006, 197, 495-504.

111. Ferris, C.D.; Huganir, R.L.; Bredt, D.S.; Cameron, A.M.; Snyder, S.H. Inositol trisphosphate receptor: Phosphorylation by protein kinase $\mathrm{C}$ and calcium calmodulin-dependent protein kinases in reconstituted lipid vesicles. Proc Natl. Acad. Sci. USA 1991, 88, 2232-2235.

112. Takasago, T.; Imagawa, T.; Furukawa, K.; Ogurusu, T.; Shigekawa, M. Regulation of the cardiac ryanodine receptor by protein kinase-dependent phosphorylation. J. Biochem. 1991, 109, $163-170$.

113. Hain, J.; Nath, S.; Mayrleitner, M.; Fleischer, S.; Schindler, H. Phosphorylation modulates the function of the calcium release channel of sarcoplasmic reticulum from skeletal muscle. Biophys. J. 1994, 67, 1823-1833.

114. Sharma, K.; Wang, L.; Zhu, Y.; Bokkala, S.; Joseph, S.K. Transforming growth factor-beta1 inhibits type I inositol 1,4,5-trisphosphate receptor expression and enhances its phosphorylation in mesangial cells. J. Biol. Chem. 1997, 272, 14617-14623.

115. Wojcikiewicz, R.J.; Luo, S.G. Phosphorylation of inositol 1,4,5-trisphosphate receptors by cAMP-dependent protein kinase. Type I, II, and III receptors are differentially susceptible to phosphorylation and are phosphorylated in intact cells. J. Biol. Chem. 1998, 273, 5670-5677.

116. Giovannucci, D.R.; Groblewski, G.E.; Sneyd, J.; Yule, D.I. Targeted phosphorylation of inositol 1,4,5-trisphosphate receptors selectively inhibits localized $\mathrm{Ca}^{2+}$ release and shapes oscillatory $\mathrm{Ca}^{2+}$ signals. J. Biol. Chem. 2000, 275, 33704-33711.

117. Vermassen, E.; Fissore, R.A.; Nadif Kasri, N.; Vanderheyden, V.; Callewaert, G.; Missiaen, L.; Parys, J.B.; De Smedt, H. Regulation of the phosphorylation of the inositol 1,4,5-trisphosphate receptor by protein kinase C. Biochem. Biophys. Res. Commun. 2004, 319, 888-893.

118. Wehrens, X.H.; Lehnart, S.E.; Reiken, S.R.; Marks, A.R. $\mathrm{Ca}^{2+} /$ calmodulin-dependent protein kinase II phosphorylation regulates the cardiac ryanodine receptor. Circ. Res. 2004, 94, e61-e70.

119. Bai, G.R.; Yang, L.H.; Huang, X.Y.; Sun, F.Z. Inositol 1,4,5-trisphosphate receptor type 1 phosphorylation and regulation by extracellular signal-regulated kinase. Biochem. Biophys. Res. Commun. 2006, 348, 1319-1327. 
120. Khan, M.T.; Wagner, L., 2nd; Yule, D.I.; Bhanumathy, C.; Joseph, S.K. Akt kinase phosphorylation of inositol 1,4,5-trisphosphate receptors. J. Biol. Chem. 2006, 281, 3731-3737.

121. Yang, L.H.; Bai, G.R.; Huang, X.Y.; Sun, F.Z. ERK binds, phosphorylates InsP3 type 1 receptor and regulates intracellular calcium dynamics in DT40 cells. Biochem. Biophys. Res. Commun. 2006, 349, 1339-1344.

122. Arguin, G.; Regimbald-Dumas, Y.; Fregeau, M.O.; Caron, A.Z.; Guillemette, G. Protein kinase C phosphorylates the inositol 1,4,5-trisphosphate receptor type 2 and decreases the mobilization of $\mathrm{Ca}^{2+}$ in pancreatoma AR4-2J cells. J. Endocrinol. 2007, 192, 659-668.

123. Caron, A.Z.; Chaloux, B.; Arguin, G.; Guillemette, G. Protein kinase C decreases the apparent affinity of the inositol 1,4,5-trisphosphate receptor type 3 in RINm5F cells. Cell Calcium. 2007, 42, 323-331.

124. Koulen, P.; Madry, C.; Duncan, R.S.; Hwang, J.Y.; Nixon, E.; McClung, N.; Gregg, E.V.; Singh, M. Progesterone potentiates IP(3)-mediated calcium signaling through Akt/PKB. Cell Physiol. Biochem. 2008, 21, 161-172.

125. Hwang, J.Y.; Duncan, R.S.; Madry, C.; Singh, M.; Koulen, P. Progesterone potentiates calcium release through IP3 receptors by an Akt-mediated mechanism in hippocampal neurons. Cell Calcium 2009, 45, 233-242.

126. Xiao, B.; Tu, J.C.; Petralia, R.S.; Yuan, J.P.; Doan, A.; Breder, C.D.; Ruggiero, A.; Lanahan, A.A.; Wenthold, R.J.; Worley, P.F. Homer regulates the association of group 1 metabotropic glutamate receptors with multivalent complexes of homer-related, synaptic proteins. Neuron 1998, 21, 707-716.

127. Naisbitt, S.; Kim, E.; Tu, J.C.; Xiao, B.; Sala, C.; Valtschanoff, J.; Weinberg, R.J.; Worley, P.F.; Sheng, M. Shank, a novel family of postsynaptic density proteins that binds to the NMDA receptor/PSD-95/GKAP complex and cortactin. Neuron 1999, 23, 569-582.

128. Tu, J.C.; Xiao, B.; Naisbitt, S.; Yuan, J.P.; Petralia, R.S.; Brakeman, P.; Doan, A.; Aakalu, V.K.; Lanahan, A.A.; Sheng, M.; Worley, P.F. Coupling of mGluR/Homer and PSD-95 complexes by the Shank family of postsynaptic density proteins. Neuron 1999, 23, 583-592.

129. Sala, C.; Piech, V.; Wilson, N.R.; Passafaro, M.; Liu, G.; Sheng, M. Regulation of dendritic spine morphology and synaptic function by Shank and Homer. Neuron 2001, 31, 115-130.

130. Gilman, A.G. G proteins: Transducers of receptor-generated signals. Annu. Rev. Biochem. 1987, $56,615-649$.

131. Simon, M.I.; Strathmann, M.P.; Gautam, N. Diversity of G proteins in signal transduction. Science 1991, 252, 802-808.

132. Rosenbaum, D.M.; Rasmussen, S.G.; Kobilka, B.K. The structure and function of G-proteincoupled receptors. Nature 2009, 459, 356-363.

133. Oldham, W.M.; Hamm, H.E. Heterotrimeric G protein activation by G-protein-coupled receptors. Nat. Rev. Mol. Cell Biol. 2008, 9, 60-71.

134. Johnston, C.A.; Siderovski, D.P. Siderovski, Receptor-mediated activation of heterotrimeric Gproteins: Current structural insights. Mol. Pharmacol. 2007, 72, 219-230.

135. Mizuno, N.; Itoh, H. Functions and Regulatory Mechanisms of Gq-Signaling Pathways. Neurosignals 2009, 17, 42-54. 
136. Devane, W.A.; Hanus, L.; Breuer, A.; Pertwee, R.G.; Stevenson, L.A.; Griffin, G.; Gibson, D.; Mandelbaum, A.; Etinger, A.; Mechoulam, R. Isolation and structure of a brain constituent that binds to the cannabinoid receptor. Science 1992, 258, 1946-1949.

137. Mechoulam, R.; Ben-Shabat, S.; Hanus, L.; Ligumsky, M.; Kaminski, N.E.; Schatz, A.R.; Gopher, A.; Almog, S.; Martin, B.R.; Compton, D.R.; Pertwee, R.G.; Griffin, G.; Bayewitch, M.; Barg, J.; Vogel, Z. Identification of an endogenous 2-monoglyceride, present in canine gut, that binds to cannabinoid receptors. Biochem. Pharmacol. 1995, 50, 83-90.

138. Sugiura, T.; Kondo, S.; Sukagawa, A.; Nakane, S.; Shinoda, A.; Itoh, K.; Yamashita, A.; Waku, K. 2-Arachidonoylglycerol: A possible endogenous cannabinoid receptor ligand in brain. Biochem. Biophys. Res. Commun.1995, 215, 89-97.

139. Gomes, I.; Grushko, J.S.; Golebiewska, U.; Hoogendoorn, S.; Gupta, A.; Heimann, A.S.; Ferro, E.S.; Scarlata, S.; Fricker, L.D.; Devi, L.A. Novel endogenous peptide agonists of cannabinoid receptors. FASEB J. 2009, 23, 3020-3029.

140. Howlett, A.C.; Fleming, R.M. Cannabinoid inhibition of adenylate cyclase. Pharmacology of the response in neuroblastoma cell membranes. Mol. Pharmacol. 1984, 26, 532-538.

141. Howlett, A.C.; Barth, F.; Bonner, T.I.; Cabral, G.; Casellas, P.; Devane, W.A.; Felder, C.C.; Herkenham, M.; Mackie, K.; Martin, B.R.; Mechoulam, R.; Pertwee, R.G. International Union of Pharmacology. XXVII. Classification of cannabinoid receptors. Pharmacol. Rev. 2002, 54, 161-202.

142. Twitchell, W.; Brown, S.; Mackie, K. Cannabinoids inhibit N- and P/Q-type calcium channels in cultured rat hippocampal neurons. J. Neurophysiol. 1997, 78, 43-50.

143. Mackie, K.; Hille, B. Cannabinoids inhibit N-type calcium channels in neuroblastoma-glioma cells. Proc. Natl. Acad. Sci. USA 1992, 89, 3825-3829.

144. Felder, C.C.; Briley, E.M.; Axelrod, J.; Simpson, J.T.; Mackie, K.; Devane, W.A. Anandamide, an endogenous cannabimimetic eicosanoid, binds to the cloned human cannabinoid receptor and stimulates receptor-mediated signal transduction. Proc. Natl. Acad. Sci. USA 1993, 90, 7656-7660.

145. Lalonde, M.R.; Jollimore, C.A.; Stevens, K.; Barnes, S.; Kelly, M.E. Cannabinoid receptormediated inhibition of calcium signaling in rat retinal ganglion cells. Mol. Vis. 2006, 12, 1160-1166.

146. Lauckner, J.E.; Hille, B.; Mackie, K. The cannabinoid agonist WIN55,212-2 increases intracellular calcium via $\mathrm{CB} 1$ receptor coupling to $\mathrm{Gq} / 11 \mathrm{G}$ proteins. Proc. Natl. Acad. Sci. USA 2005, 102, 19144-19149.

147. Abood, M.E.; Rizvi, G.; Sallapudi, N.; McAllister, S.D. Activation of the CB1 cannabinoid receptor protects cultured mouse spinal neurons against excitotoxicity. Neurosci. Lett. 2001, 309, 197-201.

148. Gilbert, G.L.; Kim, H.J.; Waataja, J.J.; Thayer, S.A. Thayer, Delta9-tetrahydrocannabinol protects hippocampal neurons from excitotoxicity. Brain Res. 2007, 1128, 61-69.

149. Hampson, A.J.; Bornheim, L.M.; Scanziani, M.; Yost, C.S.; Gray, A.T.; Hansen, B.M.; Leonoudakis, D.J.; Bickler, P.E. Dual effects of anandamide on NMDA receptor-mediated responses and neurotransmission. J. Neurochem. 1998, 70, 671-676. 
150. Shen, M.; Thayer, S.A. Thayer, Cannabinoid receptor agonists protect cultured rat hippocampal neurons from excitotoxicity. Mol. Pharmacol. 1998, 54, 459-462.

151. Liu, Q.; Bhat, M.; Bowen, W.D.; Cheng, J. Signaling pathways from CB1 receptor activation to inhibition of NMDA-mediated calcium influx and neurotoxicity in dorsal root ganglion neurons. J. Pharmacol. Exp. Ther. 2009, 331, 1062-1070.

152. Shen, M.; Piser, T.M.; Seybold, V.S.; Thayer, S.A. Cannabinoid receptor agonists inhibit glutamatergic synaptic transmission in rat hippocampal cultures. J. Neurosci. 1996, 16, $4322-4334$.

153. Kim, S.H.; Won, S.J.; Mao, X.O.; Jin, K.; Greenberg, D.A. Molecular mechanisms of cannabinoid protection from neuronal excitotoxicity. Mol. Pharmacol .2006, 69, 691-696.

154. Zhuang, S.Y.; Bridges, D.; Grigorenko, E.; McCloud, S.; Boon, A.; Hampson, R.E.; Deadwyler, S.A. Cannabinoids produce neuroprotection by reducing intracellular calcium release from ryanodine-sensitive stores. Neuropharmacology 2005, 48, 1086-1096.

155. Flammer, J.; Orgul, S.; Costa, V.P.; Orzalesi, N.; Krieglstein, G.K.; Serra, L.M.; Renard, J.P.; Stefansson, E. The impact of ocular blood flow in glaucoma. Prog. Retin. Eye Res. 2002, 21, 359-393.

156. Galanopoulos, A.; Goldberg, I. Clinical efficacy and neuroprotective effects of brimonidine in the management of glaucoma and ocular hypertension. Clin. Ophthalmol. 2009, 3, 117-122.

157. Donello, J.E.; Padillo, E.U.; Webster, M.L.; Wheeler, L.A.; Gil, D.W. alpha(2)-Adrenoceptor agonists inhibit vitreal glutamate and aspartate accumulation and preserve retinal function after transient ischemia. J. Pharmacol. Exp. Ther. 2001, 296, 216-223.

158. Baptiste, D.C.; Hartwick, A.T.; Jollimore, C.A.; Baldridge, W.H.; Chauhan, B.C.; Tremblay, F.; Kelly, M.E. Comparison of the neuroprotective effects of adrenoceptor drugs in retinal cell culture and intact retina. Invest. Ophthalmol. Vis. Sci. 2002, 43, 2666-2676.

159. Grunert, U.; Haverkamp, S.; Fletcher, E.L.; Wassle, H. Synaptic distribution of ionotropic glutamate receptors in the inner plexiform layer of the primate retina. J. Comp. Neurol. 2002, 447, 138-151.

160. Sun, D.; Rait, J.L.; Kalloniatis, M. Inner retinal neurons display differential responses to Nmethyl-D-aspartate receptor activation. J. Comp. Neurol. 2003, 465, 38-56.

161. Dreyer, E.B.; Zurakowski, D.; Schumer, R.A.; Podos, S.M.; Lipton, S.A. Elevated glutamate levels in the vitreous body of humans and monkeys with glaucoma. Arch. Ophthalmol. 1996, 114, 299-305.

162. Louzada-Junior, P.; Dias, J.J.; Santos, W.F.; Lachat, J.J.; Bradford, H.F.; Coutinho-Netto, J. Glutamate release in experimental ischaemia of the retina: An approach using microdialysis. $J$. Neurochem. 1992, 59, 358-363.

163. Neal, M.J.; Cunningham, J.R.; Hutson, P.H.; Hogg, J. Effects of ischaemia on neurotransmitter release from the isolated retina. J. Neurochem. 1994, 62, 1025-1033.

164. Perlman, J.I.; McCole, S.M.; Pulluru, P.; Chang, C.J.; Lam, T.T.; Tso, M.O. Disturbances in the distribution of neurotransmitters in the rat retina after ischemia. Curr. Eye Res. 1996, 15, $589-596$. 
165. Chizh, B.A. Low dose ketamine: A therapeutic and research tool to explore N-methyl-Daspartate (NMDA) receptor-mediated plasticity in pain pathways. J. Psychopharmacol. 2007, 21, $259-271$.

166. Pittenger, C.; Sanacora, G.; Krystal, J.H. The NMDA receptor as a therapeutic target in major depressive disorder. CNS Neurol. Disord. Drug Targets 2007, 6, 101-115.

167. Hare, W.; WoldeMussie, E.; Lai, R.; Ton, H.; Ruiz, G.; Feldmann, B.; Wijono, M.; Chun, T.; Wheeler, L. Efficacy and safety of memantine, an NMDA-type open-channel blocker, for reduction of retinal injury associated with experimental glaucoma in rat and monkey. Surv. Ophthalmol. 2001, 45 (Suppl. 3), S284-S289; discussion S285-S286.

168. Lagreze, W.A.; Knorle, R.; Bach, M.; Feuerstein, T.J. Memantine is neuroprotective in a rat model of pressure-induced retinal ischemia. Invest. Ophthalmol. Vis. Sci. 1998, 39, 1063-1066.

169. Osborne, N.N. Memantine reduces alterations to the mammalian retina, in situ, induced by ischemia. Vis. Neurosci. 1999, 16, 45-52.

170. WoldeMussie, E.; Yoles, E.; Schwartz, M.; Ruiz, G.; Wheeler, L.A. Neuroprotective effect of memantine in different retinal injury models in rats. J. Glaucoma 2002, 11, 474-480.

171. Hare, W.A.; WoldeMussie, E.; Lai, R.K.; Ton, H.; Ruiz, G.; Chun, T.; Wheeler, L. Efficacy and safety of memantine treatment for reduction of changes associated with experimental glaucoma in monkey, I: Functional measures. Invest. Ophthalmol. Vis. Sci. 2004, 45, 2625-2639.

172. Hare, W.A.; WoldeMussie, E.; Weinreb, R.N.; Ton, H.; Ruiz, G.; Wijono, M.; Feldmann, B.; Zangwill, L.; Wheeler, L. Efficacy and safety of memantine treatment for reduction of changes associated with experimental glaucoma in monkey, II: Structural measures. Invest. Ophthalmol. Vis. Sci. 2004, 45, 2640-2651.

173. WoldeMussie, E.; Ruiz, G.; Wijono, M.; Wheeler, L.A. Neuroprotection of retinal ganglion cells by brimonidine in rats with laser-induced chronic ocular hypertension. Invest. Ophthalmol. Vis. Sci.2001, 42, 2849-2855.

174. Kalapesi, F.B.; Coroneo, M.T.; Hill, M.A. Human ganglion cells express the alpha-2 adrenergic receptor: Relevance to neuroprotection. Br. J. Ophthalmol. 2005, 89, 758-763.

175. Katz, L.J.; Simmons, S.T.; Craven, E.R. Efficacy and safety of brimonidine and dorzolamide for intraocular pressure lowering in glaucoma and ocular hypertension. Curr. Med. Res. Opin. 2007, 23, 2971-2983.

176. Dong, C.J.; Guo, Y.; Wheeler, L.; Hare, W.A. Alpha2 adrenergic receptor-mediated modulation of cytosolic $\mathrm{Ca}++$ signals at the inner plexiform layer of the rat retina. Invest. Ophthalmol. Vis. Sci. 2007, 48, 1410-1415.

177. Lakhlani, P.P.; Lovinger, D.M.; Limbird, L.E. Genetic evidence for involvement of multiple effector systems in alpha 2A-adrenergic receptor inhibition of stimulus-secretion coupling. Mol. Pharmacol. 1996, 50, 96-103.

178. Dong, C.J.; Guo, Y.; Agey, P.; Wheeler, L.; Hare, W.A. Alpha2 adrenergic modulation of NMDA receptor function as a major mechanism of RGC protection in experimental glaucoma and retinal excitotoxicity. Invest. Ophthalmol. Vis. Sci. 2008, 49, 4515-4522.

179. Delmas, P.; Abogadie, F.C.; Milligan, G.; Buckley, N.J.; Brown, D.A. Betagamma dimers derived from Go and Gi proteins contribute different components of adrenergic inhibition of $\mathrm{Ca}^{2+}$ channels in rat sympathetic neurones. J. Physiol. 1999, 518, 23-36. 
180. Cowburn, R.F.; Popescu, B.O.; Ankarcrona, M.; Dehvari, N.; Cedazo-Minguez, A. Presenilinmediated signal transduction. Physiol. Behav. 2007, 92, 93-97.

181. Lah, J.J.; Heilman, C.J.; Nash, N.R.; Rees, H.D.; Yi, H.; Counts, S.E.; Levey, A.I. Light and electron microscopic localization of presenilin-1 in primate brain. J. Neurosci. 1997, 17, 1971-1980.

182. Lee, M.K.; Slunt, H.H.; Martin, L.J.; Thinakaran, G.; Kim, G.; Gandy, S.E.; Seeger, M.; Koo, E.; Price, D.L.; Sisodia, S.S. Expression of presenilin 1 and 2 (PS1 and PS2) in human and murine tissues. J. Neurosci. 1996, 16, 7513-7525.

183. Levey, A.I.; Heilman, C.J.; Lah, J.J.; Nash, N.R.; Rees, H.D.; Wakai, M.; Mirra, S.S.; Rye, D.B.; Nochlin, D.; Bird, T.D.; Mufson, E.J. Presenilin-1 protein expression in familial and sporadic Alzheimer's disease. Ann. Neurol. 1997, 41, 742-753.

184. Nakajima, M.; Moriizumi, E.; Koseki, H.; Shirasawa, T. Presenilin 1 is essential for cardiac morphogenesis. Dev. Dyn. 2004, 230, 795-799.

185. Shen, J.; Bronson, R.T.; Chen, D.F.; Xia, W.; Selkoe, D.J.; Tonegawa, S. Skeletal and CNS defects in Presenilin-1-deficient mice. Cell 1997, 89, 629-639.

186. Donoviel, D.B.; Hadjantonakis, A.K.; Ikeda, M.; Zheng, H.; Hyslop, P.S.; Bernstein, A. Mice lacking both presenilin genes exhibit early embryonic patterning defects. Genes. Dev. 1999, 13, 2801-2810.

187. Borchelt, D.R.; Thinakaran, G.; Eckman, C.B.; Lee, M.K.; Davenport, F.; Ratovitsky, T.; Prada, C.M.; Kim, G.; Seekins, S.; Yager, D.; Slunt, H.H.; Wang, R.; Seeger, M.; Levey, A.I.; Gandy, S.E.; Copeland, N.G.; Jenkins, N.A.; Price, D.L.; Younkin, S.G.; Sisodia, S.S. Familial Alzheimer's disease-linked presenilin 1 variants elevate Abeta1-42/1-40 ratio in vitro and in vivo. Neuron 1996, 17, 1005-1013.

188. Cedazo-Minguez, A.; Popescu, B.O.; Ankarcrona, M.; Nishimura, T.; Cowburn, R.F. The presenilin 1 deltaE9 mutation gives enhanced basal phospholipase $\mathrm{C}$ activity and a resultant increase in intracellular calcium concentrations. J. Biol. Chem. 2002, 277, 36646-36655.

189. Chyung, J.H.; Raper, D.M.; Selkoe, D.J. Gamma-secretase exists on the plasma membrane as an intact complex that accepts substrates and effects intramembrane cleavage. J. Biol. Chem. 2005, 280, 4383-4392.

190. Lee, M.K.; Borchelt, D.R.; Kim, G.; Thinakaran, G.; Slunt, H.H.; Ratovitski, T.; Martin, L.J.; Kittur, A.; Gandy, S.; Levey, A.I.; Jenkins, N.; Copeland, N.; Price, D.L.; Sisodia, S.S. Hyperaccumulation of FAD-linked presenilin 1 variants in vivo. Nat. Med. 1997, 3, 756-760.

191. Green, K.N.; LaFerla, F.M. Linking calcium to Abeta and Alzheimer's disease. Neuron 2008, 59, 190-194.

192. Laudon, H.; Hansson, E.M.; Melen, K.; Bergman, A.; Farmery, M.R.; Winblad, B.; Lendahl, U.; von Heijne, G.; Naslund, J. A nine-transmembrane domain topology for presenilin 1. J. Biol. Chem. 2005, 280, 35352-35360.

193. Thinakaran, G.; Borchelt, D.R.; Lee, M.K.; Slunt, H.H.; Spitzer, L.; Kim, G.; Ratovitsky, T.; Davenport, F.; Nordstedt, C.; Seeger, M.; Hardy, J.; Levey, A.I.; Gandy, S.E.; Jenkins, N.A.; Copeland, N.G.; Price, D.L.; Sisodia, S.S. Endoproteolysis of presenilin 1 and accumulation of processed derivatives in vivo. Neuron 1996, 17, 181-190. 
194. Spasic, D.; Tolia, A.; Dillen, K.; Baert, V.; De Strooper, B.; Vrijens, S.; Annaert, W. Presenilin-1 maintains a nine-transmembrane topology throughout the secretory pathway. J. Biol. Chem. 2006, 281, 26569-26577.

195. Capell, A.; Grunberg, J.; Pesold, B.; Diehlmann, A.; Citron, M.; Nixon, R.; Beyreuther, K.; Selkoe, D.J.; Haass, C. The proteolytic fragments of the Alzheimer's disease-associated presenilin-1 form heterodimers and occur as a 100-150-kDa molecular mass complex. J. Biol. Chem. 1998, 273, 3205-3211.

196. Ribaut-Barassin, C.; Dupont, J.L.; Haeberle, A.M.; Bombarde, G.; Huber, G.; Moussaoui, S.; Mariani, J.; Bailly, Y. Alzheimer's disease proteins in cerebellar and hippocampal synapses during postnatal development and aging of the rat. Neuroscience 2003, 120, 405-423.

197. Leissring, M.A.; Akbari, Y.; Fanger, C.M.; Cahalan, M.D.; Mattson, M.P.; LaFerla, F.M. Capacitative calcium entry deficits and elevated luminal calcium content in mutant presenilin-1 knockin mice. J. Cell. Biol. 2000, 149, 793-798.

198. Leissring, M.A.; LaFerla, F.M.; Callamaras, N.; Parker, I. Subcellular mechanisms of presenilinmediated enhancement of calcium signaling. Neurobiol. Dis. 2001, 8, 469-478.

199. Leissring, M.A.; Yamasaki, T.R.; Wasco, W.; Buxbaum, J.D.; Parker, I.; LaFerla, F.M. Calsenilin reverses presenilin-mediated enhancement of calcium signaling. Proc. Natl. Acad. Sci. USA 2000, 97, 8590-8593.

200. Mattson, M.P.; Zhu, H.; Yu, J.; Kindy, M.S. Presenilin-1 mutation increases neuronal vulnerability to focal ischemia in vivo and to hypoxia and glucose deprivation in cell culture: Involvement of perturbed calcium homeostasis. J. Neurosci. 2000, 20, 1358-1364.

201. Nelson, O.; Tu, H.; Lei, T.; Bentahir, M.; de Strooper, B.; Bezprozvanny, I. Familial Alzheimer disease-linked mutations specifically disrupt $\mathrm{Ca}^{2+}$ leak function of presenilin 1. J. Clin. Invest. 2007, 117, 1230-1239.

202. Smith, I.F.; Green, K.N.; LaFerla, F.M. Calcium dysregulation in Alzheimer's disease: Recent advances gained from genetically modified animals. Cell Calcium 2005, 38, 427-437.

203. Takeda, T.; Asahi, M.; Yamaguchi, O.; Hikoso, S.; Nakayama, H.; Kusakari, Y.; Kawai, M.; Hongo, K.; Higuchi, Y.; Kashiwase, K.; Watanabe, T.; Taniike, M.; Nakai, A.; Nishida, K.; Kurihara, S.; Donoviel, D.B.; Bernstein, A.; Tomita, T.; Iwatsubo, T.; Hori, M.; Otsu, K. Presenilin 2 regulates the systolic function of heart by modulating $\mathrm{Ca}^{2+}$ signaling. FASEB J. 2005, 19, 2069-2071.

204. Zatti, G.; Burgo, A.; Giacomello, M.; Barbiero, L.; Ghidoni, R.; Sinigaglia, G.; Florean, C.; Bagnoli, S.; Binetti, G.; Sorbi, S.; Pizzo, P.; Fasolato, C. Presenilin mutations linked to familial Alzheimer's disease reduce endoplasmic reticulum and Golgi apparatus calcium levels. Cell Calcium 2006, 39, 539-550.

205. Zatti, G.; Ghidoni, R.; Barbiero, L.; Binetti, G.; Pozzan, T.; Fasolato, C.; Pizzo, P. The presenilin 2 M239I mutation associated with familial Alzheimer's disease reduces $\mathrm{Ca}^{2+}$ release from intracellular stores. Neurobiol. Dis. 2004, 15, 269-278.

206. Reddy, P.H.; McWeeney, S. Mapping cellular transcriptosomes in autopsied Alzheimer's disease subjects and relevant animal models. Neurobiol. Aging 2006, 27, 1060-1077.

207. Khachaturian, Z.S. Hypothesis on the regulation of cytosol calcium concentration and the aging brain. Neurobiol. Aging 1987, 8, 345-346. 
208. Mattson, M.P. Pathways towards and away from Alzheimer's disease. Nature 2004, 430, 631-639.

209. Li, D.; Parks, S.B.; Kushner, J.D.; Nauman, D.; Burgess, D.; Ludwigsen, S.; Partain, J.; Nixon, R.R.; Allen, C.N.; Irwin, R.P.; Jakobs, P.M.; Litt, M.; Hershberger, R.E. Mutations of presenilin genes in dilated cardiomyopathy and heart failure. Am. J. Hum. Genet. 2006, 79, 1030-1039.

210. Lee, J.A.; Allen, D.G. Changes in intracellular free calcium concentration during long exposures to simulated ischemia in isolated mammalian ventricular muscle. Circ. Res. 1992, 71, 58-69.

211. Murphy, E.; Steenbergen, C. Mechanisms underlying acute protection from cardiac ischemiareperfusion injury. Physiol. Rev. 2008, 88, 581-609.

212. Vinten-Johansen, J.; Jiang, R.; Reeves, J.G.; Mykytenko, J.; Deneve, J.; Jobe, L.J. Inflammation, proinflammatory mediators and myocardial ischemia-reperfusion Injury. Hematol. Oncol. Clin. North Am. 2007, 21, 123-145.

213. Mohuczy, D.; Qian, K.; Phillips, M.I. Presenilins in the heart: Presenilin-2 expression is increased by low glucose and by hypoxia in cardiac cells. Regul. Pept. 2002, 110, 1-7.

214. Tu, H.; Nelson, O.; Bezprozvanny, A.; Wang, Z.; Lee, S.F.; Hao, Y.H.; Serneels, L.; De Strooper, B.; Yu, G.; Bezprozvanny, I. Presenilins form ER $\mathrm{Ca}^{2+}$ leak channels, a function disrupted by familial Alzheimer's disease-linked mutations. Cell 2006, 126, 981-993.

215. Pack-Chung, E.; Meyers, M.B.; Pettingell, W.P.; Moir, R.D.; Brownawell, A.M.; Cheng, I.; Tanzi, R.E.; Kim, T.W. Presenilin 2 interacts with sorcin, a modulator of the ryanodine receptor. J. Biol. Chem. 2000, 275, 14440-14445.

216. Meyers, M.B.; Pickel, V.M.; Sheu, S.S.; Sharma, V.K.; Scotto, K.W.; Fishman, G.I. Association of sorcin with the cardiac ryanodine receptor. J. Biol. Chem. 1995, 270, 26411-26418.

217. Grynkiewicz, G.; Poenie, M.; Tsien, R.Y. A new generation of $\mathrm{Ca}^{2+}$ indicators with greatly improved fluorescence properties. J. Biol. Chem. 1985, 260, 3440-3450.

218. Subach, F.V.; Patterson, G.H.; Manley, S.; Gillette, J.M.; Lippincott-Schwartz, J.; Verkhusha, V.V. Photoactivatable mCherry for high-resolution two-color fluorescence microscopy. Nat. Meth. 2009, 6, 153-159.

219. Gupta, S.; Singh, R.K.; Nanda, K.; Chatterjee, M.; Tiwari, A.; Sundaram, S.; Gupta, D.; Chugh, A.; Dastidar, S.; Ray, A. Ratiometric $\mathrm{Ca}+2$ measurement in human recombinant muscarinic receptor subtypes using the Flexstation scanning fluorometer. J. Recept. Signal. Transduct. Res. 2009, 29, 100-106.

220. Kukkonen, J.P. An easy ratiometric compensation for the extracellular $\mathrm{Ca}^{2+}$ indicator-caused fluorescence artifact. Anal. Biochem.2009, 390, 212-214.

221. Heisenberg, W. Über den anschaulichen Inhalt der quantentheoretischen Kinematik und Mechanik. Z. Phys. A-Hadron. Nucl. 1927, 43, 172-198.

222. Mank, M.; Griesbeck, O. Genetically encoded calcium indicators. Chem. Rev 2008, 108, $1550-1564$.

223. Tian, L.; Hires, S.A.; Mao, T.; Huber, D.; Chiappe, M.E.; Chalasani, S.H.; Petreanu, L.; Akerboom, J.; McKinney, S.A.; Schreiter, E.R.; Bargmann, C.I.; Jayaraman, V.; Svoboda, K.; Looger, L.L. Imaging neural activity in worms, flies and mice with improved GCaMP calcium indicators. Nat. Methods 2009, 6, 875-881. 
224. Hell, S.W. Far-field optical nanoscopy. Science 2007, 316, 1153-1158.

225. Hell, S.W. Toward fluorescence nanoscopy. Nat. Biotechnol. 2003, 21, 1347-1355.

226. Pawley, J.B. Handbook of Biological Confocal Microscopy, 3rd ed.; Springer: New York, USA, 2006; pp: 985.

227. Huang, B.; Bates, M.; Zhuang, X. Super-resolution fluorescence microscopy. Annu. Rev. Biochem. 2009, 78, 993-1016.

228. Hell, S.W.; Wichmann, J. Breaking the diffraction resolution limit by stimulated emission: Stimulated-emission-depletion fluorescence microscopy. Opt. Lett. 1994, 19, 780-782.

229. Klar, T.A.; Hell, S.W. Subdiffraction resolution in far-field fluorescence microscopy. Opt. Lett. 1999, 24, 954-956.

230. Hess, S.T.; Girirajan, T.P.; Mason, M.D. Ultra-high resolution imaging by fluorescence photoactivation localization microscopy. Biophys. J. 2006, 91, 4258-4272.

231. Betzig, E.; Patterson, G.H.; Sougrat, R.; Lindwasser, O.W.; Olenych, S.; Bonifacino, J.S.; Davidson, M.W.; Lippincott-Schwartz, J.; Hess, H.F. Imaging intracellular fluorescent proteins at nanometer resolution. Science 2006, 313, 1642-1645.

232. Neil, M.A.A.; Juskaitis, R.; Wilson, T. Method of obtaining optical sectioning by using structured light in a conventional microscope. Opt. Lett. 1997, 22, 1905-1907.

233. Gustafsson, M.G. Nonlinear structured-illumination microscopy: Wide-field fluorescence imaging with theoretically unlimited resolution. Proc. Natl. Acad. Sci. USA 2005, 102, 13081-13086.

234. Begley, R.F.; Harvey, A.B.; Byer, R.L. Coherent anti-Stokes Raman spectoscopy. Appl. Phys. Lett. 1974, 25, 387-390.

235. Hell, S.W.; Stelzer, E.H.; Lindek, S.; Confocal microscopy with an increased detection aperture: Type-B 4pi confocal microscopy. Opt. Lett. 1994, 19, 222.

236. Rust, M.J.; Bates, M.; Zhuang, X. Sub-diffraction-limit imaging by stochastic optical reconstruction microscopy (STORM). Nat. Methods 2006, 3, 793-795.

237. Bano, D.; Nicotera, P. $\mathrm{Ca}^{2+}$ signals and neuronal death in brain ischemia. Stroke 2007, $38,674-676$.

238. Bezprozvanny, I. Calcium signaling and neurodegenerative diseases. Trends Mol.Med. 2009, 15, 89-100.

(C) 2010 by the authors; licensee Molecular Diversity Preservation International, Basel, Switzerland. This article is an open-access article distributed under the terms and conditions of the Creative Commons Attribution license (http://creativecommons.org/licenses/by/3.0/). 